إنقر ائية مجلة الإرشاد الزراعى والمتغيرات المؤثرة عليها بين أعضاء مجالس إدارات الجمعيات التعاونية الزراعية بمركز إيتاى البارود - محافظة البحيرة

$$
\text { مصطفى صبرى صالح' }
$$

التعليمى، فى حين لا يوجد أي أحد من المبحوثين فى

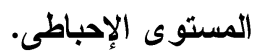
r- تبين وجود فروق معنوية بين موضوعات مجلة الإرشاد الزراعى المدروسة وفقا لمتوسطات درجة إنقرائيتها. ب- تبين أن خسة متغيرات مستقلة مجتمعة تؤثر معنويا فى

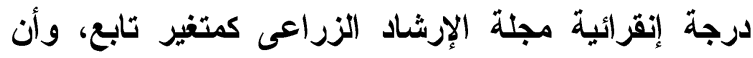
هذه المتغيرات الخمسة مجتمعة مسئولة عن تفسير الإنية

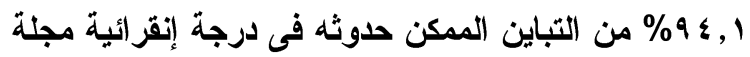

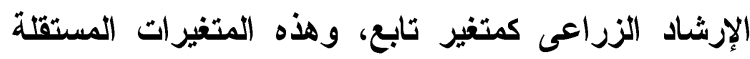

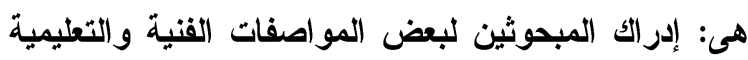

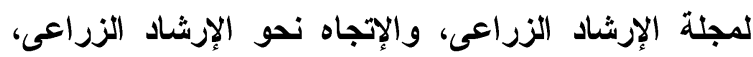
ودافعية الإججاز، و المستوى التطليمى، وقيادة الرأى. ع- تبين أن أكثر المتغيرات المستقلة تأثيرا فى المتغير التابع

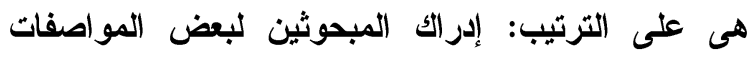
الفنية و التعليمية لمجلة الإرشاد الزراعى، يليه متغير الإنجاه

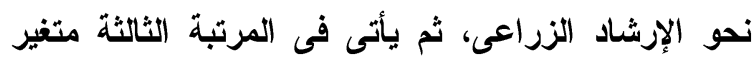

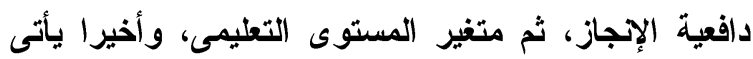
متغير قيادة الرأى. - مأن الكلمات المفتاحية: مجلة الإرشاد الزراعى- الإنقرائية-

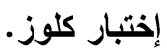

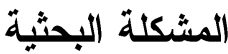

تعد المطبوعات الإرشادية الزراعية أحد الطرق الهامة

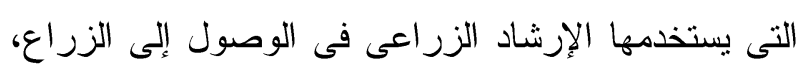

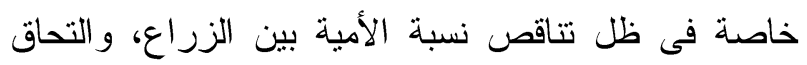

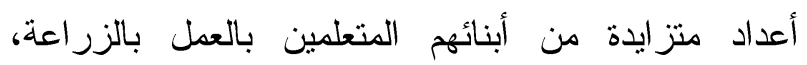

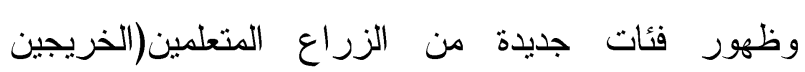

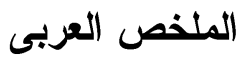

يستهلف هذا البحث بصفة رئيسية، دراسة إنقرائية مجلة الإرشاد الزراعى، والمتغيرات المؤثرة عليها بين أعضاء

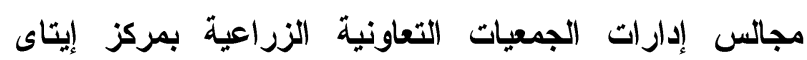
البارود بححافظة البحيرة، وذلك من خلات تحقيق الأهداف

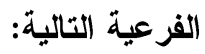

1) التعرف على بعض الخصائص الثخصية المميزة لأعضاء مجالس إدارات الجمعيات التعاونية الزراعية بمركز إيتاى

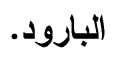

r) التعرف على مستوى إنقرائية مجلة الإششاد الزراعى بين أعضاء مجالس إدارات الجمعيات التعاونية الزراعية بمركز

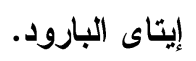

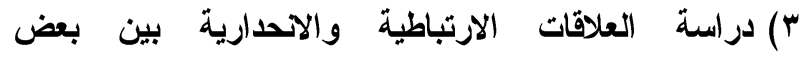
الخصائص المميزة لأعضاء مجالس إدارات الجمعيات التعاونية الزراعية بمركز إيتاى البارود، ودرجة إنقرائية مجلة الإرشاد الزراعى بينهم. وقد تم استيفاء إختبار كلوز للإفقرائية والبيانات الميدانية من عينة عشوائية قوامها له به مبحوثا، وهم جميع أعضاء مجالس إدارات سبع جمعيات تعاونية زراعية مختارة عشو ائيا بمركز إيتاى البارود، وقد استخذمت النسب المئوية، والجداول التكرارية، والمتوسط الحسابى، والاتحر اف المعبارى، وإختبار (ت)، و(ت)، و(Isd)، ومعامل الارتباط البسيط، والاتحدار

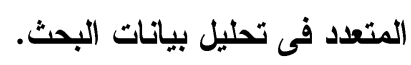

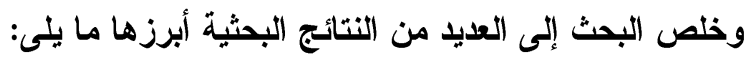

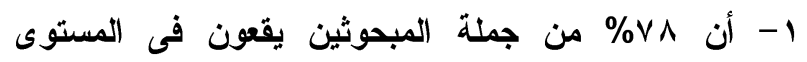

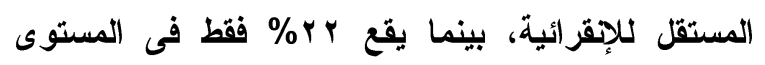


المجلة فى نطاق الإطار الدلالى لمعانى الكلمات والجمل و الموضوعات لكل من محررى المجلة والمستهوفين

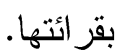
وتؤكد ننائج العديد من الدراسات أنه بالرغم من كون مجلة الإرشاد الزراعى تمثل مصدرا مرجعيا يستقى منه

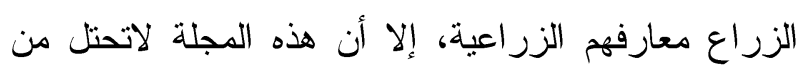

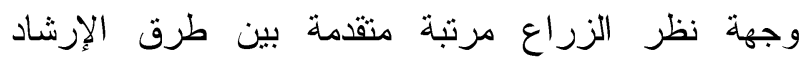

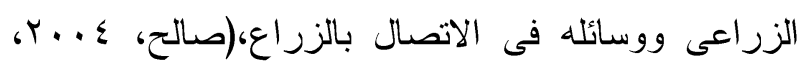

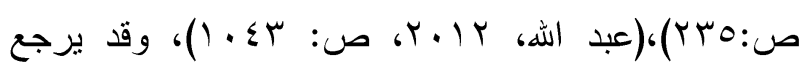
ذلك الى إنخفاض مستوى إنقرائتنها إضافة إلى الثى التأثثر السلبى للعديد من المتغيرات التى قد نعزى إلى الفى القزاء

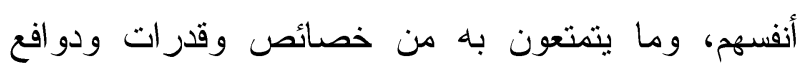

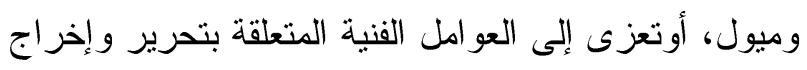

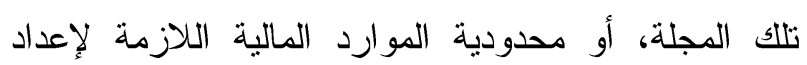

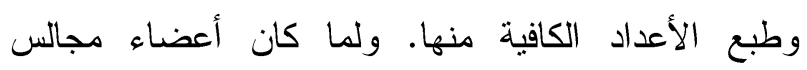

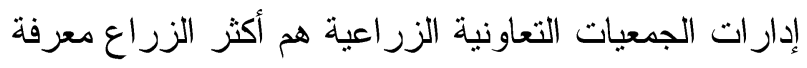

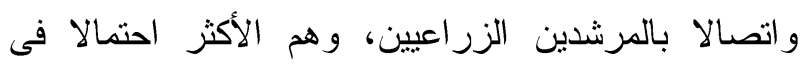

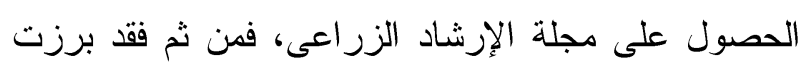

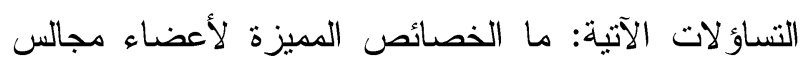

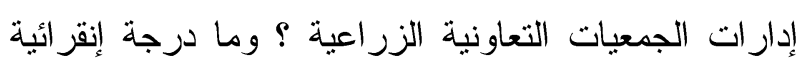

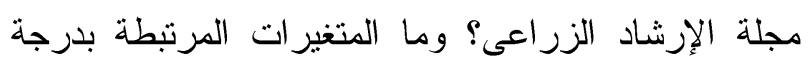

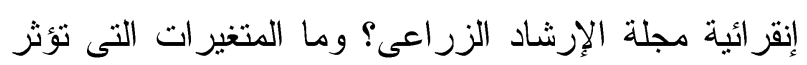
فيها؟ ولاشك أن نتائج هذا البحث سوف تجيب على تلك

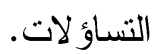

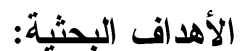

() التعرف على بعض الخصائص الثخصية المميزة لأعضاء مجالس إدارات الجمعيات التعاونية الزراعية بمركز إيتاى البارود فى محافظة البحيرة.
و المستثمرين). ويصدر الجهاز الإرشادى تلك المطبوعات

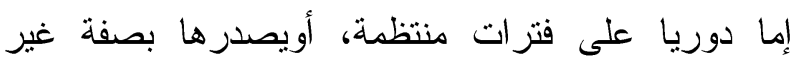
منتظمة تبعا للحاجة إليها، وتعتمد المطبوعات الإرشادية الزراعية على استخدام الرموز الإتصالية اللفظية وغير

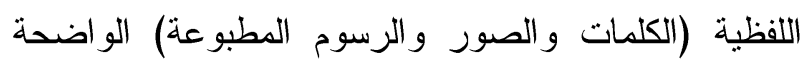
و الدفهومة، ويراعى فى كتابتها العتاصر الأولية للكتابة الإرشادية، وهى الدقة والإيجاز والبساطة و السهولة

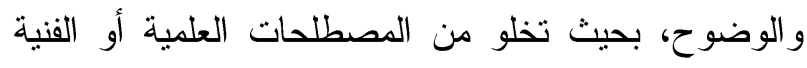

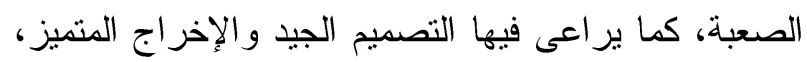
مما يفيد فى لفت نظر وجذب انتباه القراء إليها، و إثارة

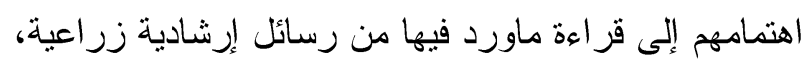

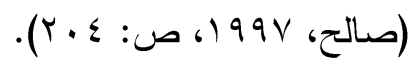

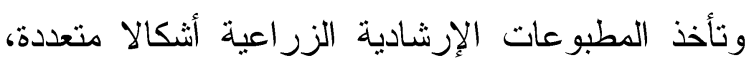

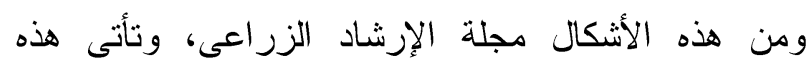

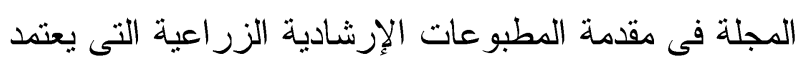

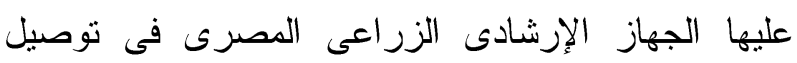

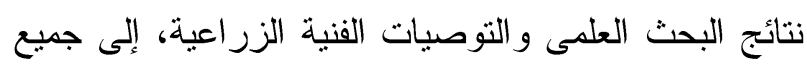

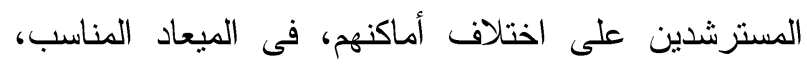
ليكونوا على علم بمختلف التوصيات الفنية الإرشادية

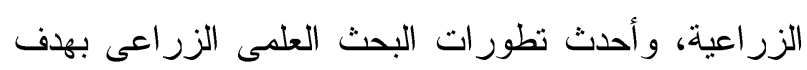

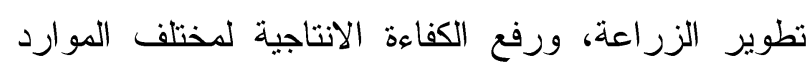
الزر اعية، وبالتالى زيادة الدخل القومى الزر اعى، و الدخول

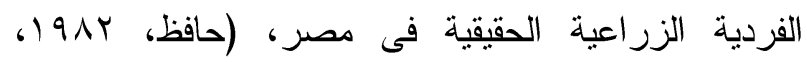

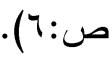
ولكى تحقق مجلة الإرشاد الزراعى الفعالية المطلوبة منها يجب أن يراعى فيها المضمون المناسب، والتحرير و الإخر اج الجيدين حتى ينسنى للمسترشدين قراءتها، وفهمها

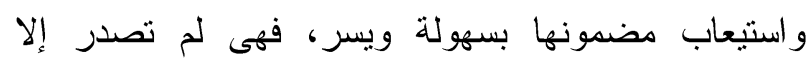

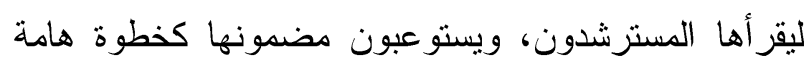
نحو التطبيق الفعلى لذلك المضمون، وبالتالى تحقيق الغاية من صدورها، لذا كان من الضرورى أن يقع محتوى لخئى 
مجلة الإسكندرية للتبادل العلمى - (مجلد Tr العددء) أكتوبر - ديسمبر 1 ـ ب

ا ـ الإنقر ائية هى الدرجة التي تمثل مقدار صعوبة فهم طلبة صف معين لموضوع ما، وتقدر هذه الدرجة بمتوسط الإنه

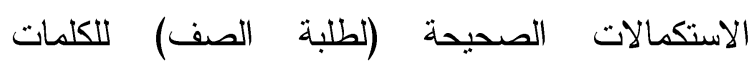
المحذوفة من الموضوع وفق إختبار كلوز، (داوود،

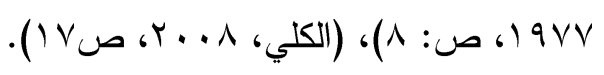

r. الإنقرائية هى درجة السهولة والصعوبة في فهم، و استيعاب المقروء من قبل القارئ بعد تقاعل، وتو افق وهي

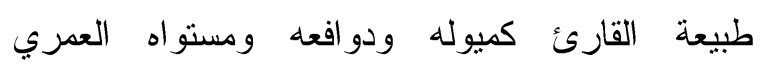
و الفكري، وطبيعة المقروء من حيث الثكل و المضمون

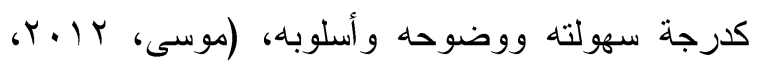
ص: מי).

r. الإنقر ائية تعنى مدى سهولة المادة المقرو عة وصعوبتها،

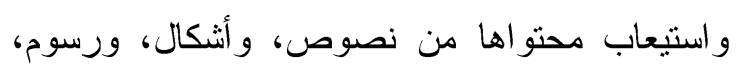
ومصطلحات علمية، ومفاهيم، ويستخدم مصطلح الإنقرائية فى الدلالة على وضوح الخط أو المادة المقروءة، وسهولة القراءة، بالإضافة إلى ميل القارئ

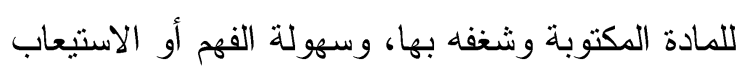

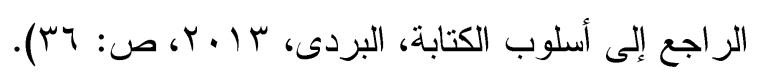

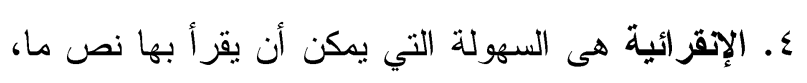
وترجع إلى كل العوامل التي يمكن أن تؤثر في نجاح قز اءة النص وفهمه، ويقع ضمن ذلك الهنمام القارئ

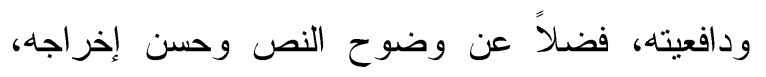

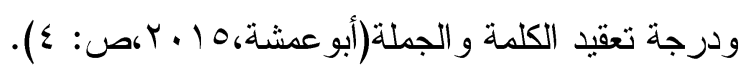
هـ ويعرف Johnson الإنقر ائية بأنها السهولة التي يمكن أن

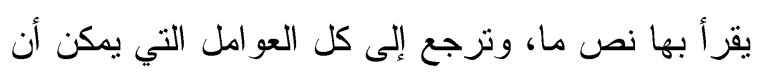
تؤثر في نجاح قراءة النص وفهمه، ويقع ضمن ذلك إنى

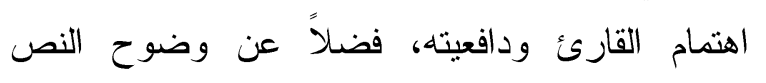

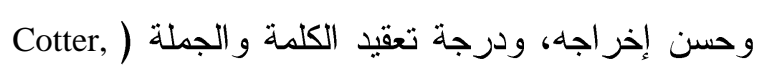
.(2003, p: 15 r) التعرف على درجة إنقرائية مجلة الإرشاد الزراعى بين

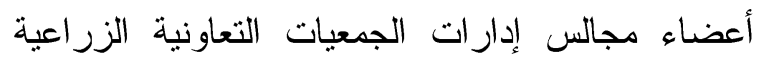
بمركز إيتاى البارود فى محافظة البحيرة.

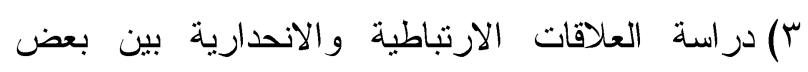
الخصائص المميزة لأعضاء مجالس إدارات الجمعيات التعاونية الزر اعية بمركز إيتاى البارود، ودرجة إنقرائية مجلة الإرشاد الزر اعى بينهم. الفروض البحثية: - ان (1) توجد فروق معنوية بين موضوعات مجلة الإرشاد الزر اعى المدروسة وفقا لدرجة إنقر ائيتها. r) تتأثر درجة إنقرائية مجلة الإرشاد الزر اعى بين أعضاء

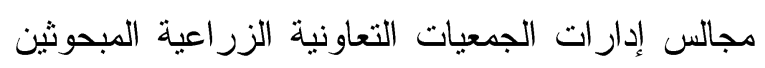
كمتغير تابع بكل من المتغير ات المستقلة الآتية مجتمعة: المستوى التعليمى للمبحوثين، وحيازة الأرض الزر اعية،

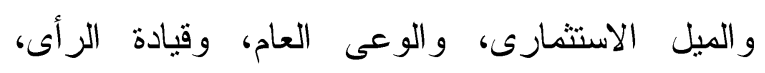

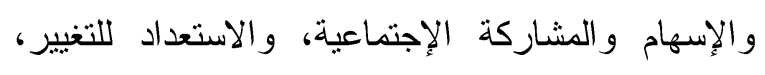

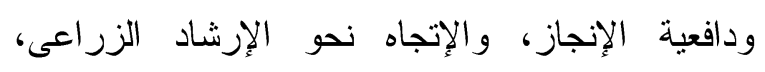
و إدراك المبحوثين لبعض المو اصفات الفنية والتعليمية لمجلة الإزشاد الزر اعى. ويتم إختبار هذه الفروض فى صورتها الصفرية. الإطار الإظرى:

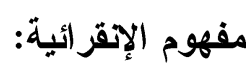
القر اءة هى وسيلة اتصال بين القارئ و المادة المقروءة،

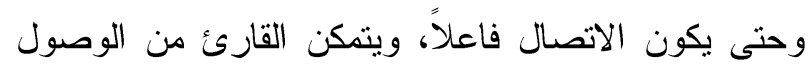

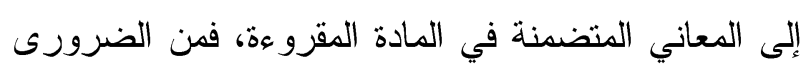
أن تكون المادة المقروءة مناسبة لقدرة القارئ ليتمكن من الانجذاب إليها، واستخراج معانيها. وقد تباينت تعريفات

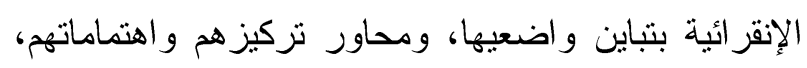
وفيما يلى استعر اض لبعض تلك التعريفات: 
عند قرائتها. ذلك أن ميل القارىء الى القراءة واهتمامه

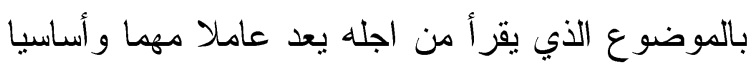
في تحديد سهولة النص المقروء بالنسبة له، (البسيوني،

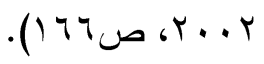

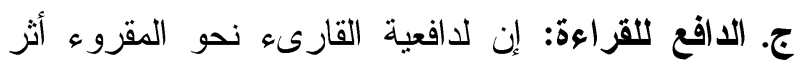

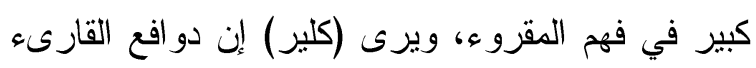

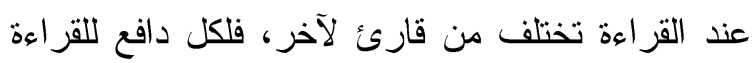

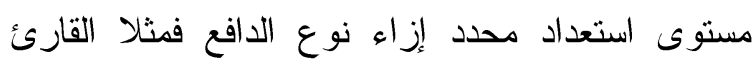

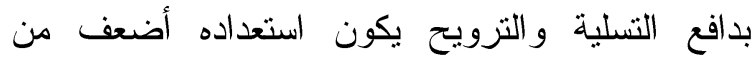

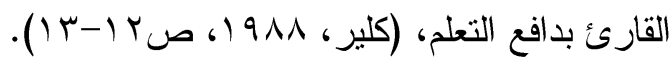

د. المستوى التعليمي والثقافي للقارىء: هناك علاقة

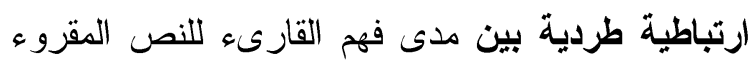

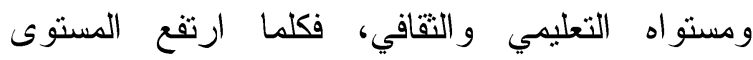
التعليمي والتقافي للقارىء كلما ارتفعت نسبة فهمه

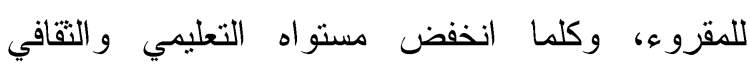

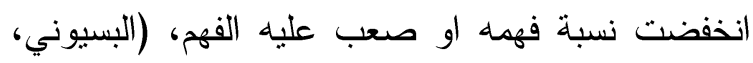

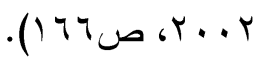
ثانيا: العو امل التى تتعلق بالنص:

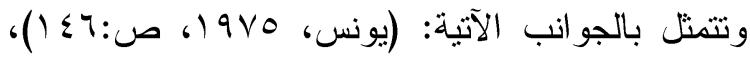

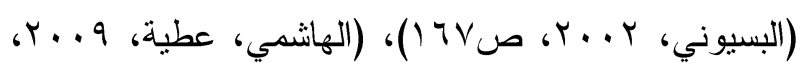

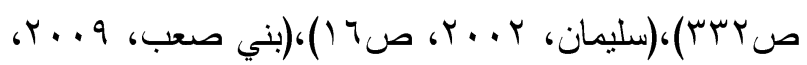

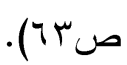
أ.المفردات: تؤثر الدفردات تأثثر ا كبير ا على سهولة النص

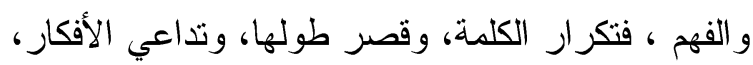
واستخدام الكلمات الدجردة، واستخدام الأفعال مقابل

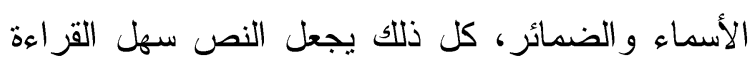
و الفهم،

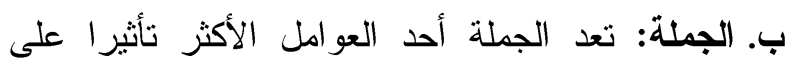

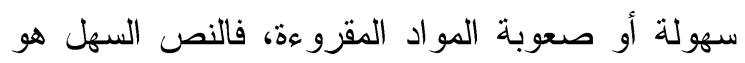
الذى يتضمن الجمل القصيرة قليلة الكلمات، التى تخلو

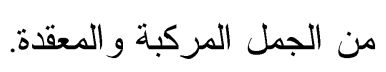

العو امل المؤثرة في الإنقر ائية: - مائ

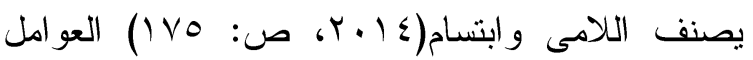
التى تتأثر بها الإنقر ائية فى: 1- عو امل تتعلق بالطالب، وهى: ميوله وخبرته السابقة، ودافعيته للقر اءة، ومستو اه التعليمى و الثقافى. r-عوامل تتعلق بالنص: ومنها الكلمة و الجملة ودرجة تعقيد النص، وعرض الأفكار، و الصور و الرسوم، و الطباعة و التنظيم.

ب-عوامل فيزيائية: ومنها الحرارة، و الضوء، والحالة الجسمانية، وكيفية الجلوس للقراءة. ع-طبيعة الأساليب اللغوية و البيانية.

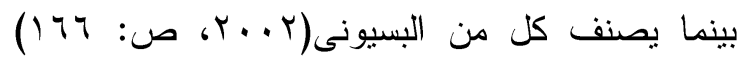
و (2002, p: 131) Lu العوامل التى تؤثر فى الإنقرائية

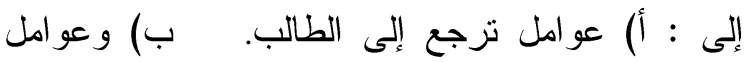
ترجع إلى النص.

وفيما يلى تفصيل لأهم العوامل المؤثرة على الإنقرائية على النحو النتالى: أولا: العو امل المرتبطة بالقارى؟:

أ. الخبرة السابقة: للخبرة السابقة أهية كبيرة، وتأثير بأنير و واضح في استيعاب القراء وفهمه للنص المقدم للقز اءة،

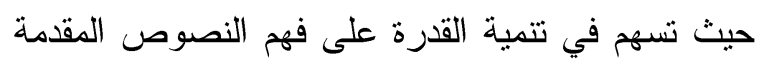
إليهم، من خلال الربط بين الخبرات السابقة، وبين

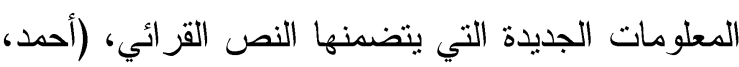

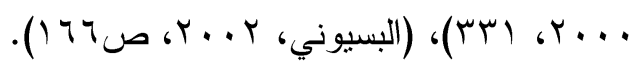

ب. الميول: إن إغفال ميول القراء، وعدم استثارة

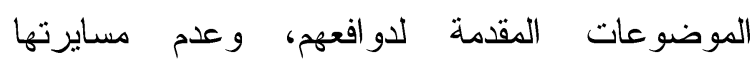
لحاجاتهم، وإثباعها لرغباتهم، من أهم العوامل المؤثرة

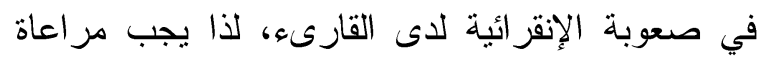

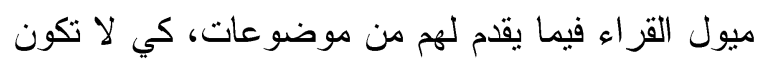
عبئا ثقيلا عليهم، مما تؤدي إلى عدم شعور هم بالارتياح 


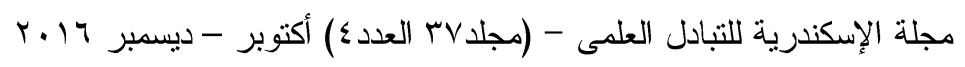

و المسافات بين الكلمات والأسطر، ونوعية الورق،

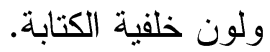

ح. التنظيم: تنظيم النص يعتبر من أهم العوامل المساعدة

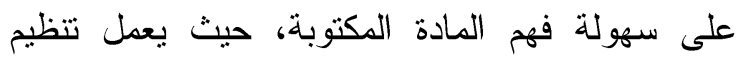
النص على مد الجسور بين المفهوم و القارئ لمساعدته على إن ما يتعلمه الآن له علاقة بما عرفه بالفعل.

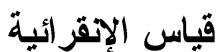

يوجد أكثر من أسلوب لقياس الإنقرائية من أهمها:

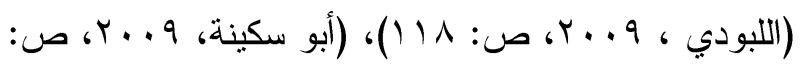

1. أسلوب تقدير الخبر اء أو المحكمبن. r. أسلوب إستخدام معادلات (صيغ) الإنقر ائية. r. أسلوب إختبار الإستيعاب. ع أسلوب إختبار التكملة. ه. أسلوب إختبار التتمة (إختبار كلوز). إختبار كلوز أو(إختبار التتمة): بُني إختبار كلوز

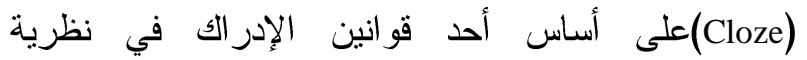
الجشتالت، ومؤدى هذا القانون أن الفرد لايه إستعداد فطري لإكمال الموقف الناقص متخلصاً بذلك من التوتر الذي ينشأ

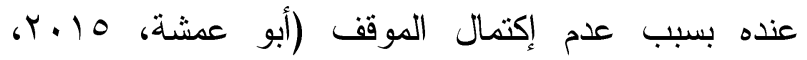

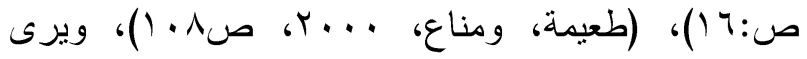
تايلور أن هذا الأسلوب هو أداة ثابتة في قياس الإنقرائية، كما يعرف تايلور إختبار كلوز (التتمة) بأنه إقتباس من

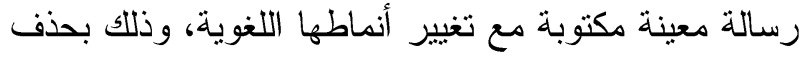
أجز اء منها بنظام معين، ثم تقديمها لبعض المتلقين (قراءً أو

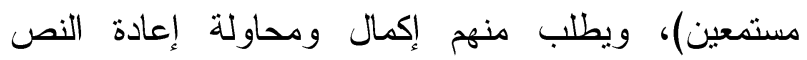

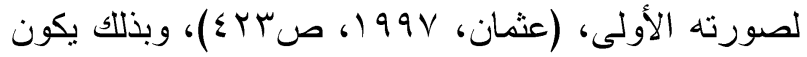

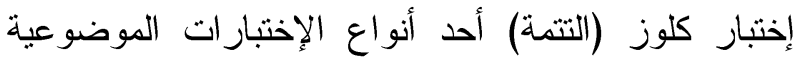
التى تتضمن تقديم مجموعة من النصوص المكتوبة إلى الى القراء، محذوف منها عدد من الكلمات، وفق نظام معين،
ج. درجة تعقيد البناء اللغوي: الرسالة السهلة هى التى تكون بعيدة عن تعقيدات البناء اللغوى، وتخلو من الرناهن

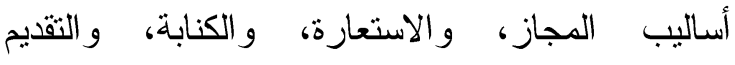

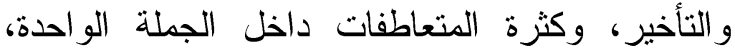
ويقل فيها استعمال الكلمات المزيدة، والتزاكيب المبنية للمجهول قباسا بالمبنية للمعلوم. كم لاتتباعد أركان الجملة عن بعضها، ومن الضرورى أن تكون الرسالة

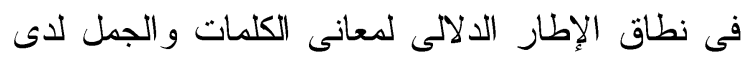

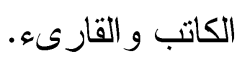

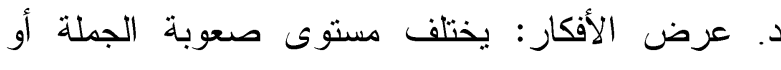
سهولتها تبعا لعدد الأفكار التي تثتنمل عليهاهومن ثم الثماري يجب مر اعاة السهولة و الدقة و التنظيم في عرض أفكار

$$
\text { الموضوع. }
$$

ه. الرسوم والصور: نقرب الصور و الرسوم التوضيحية

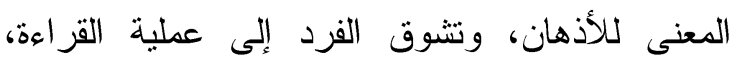
وتثير انتباهه، وتحفز ميله، فهى عادة ما تعتبر جزءا لتهاء تكميليا مدعما لما يتعلمه القارى، وتختلف مساحة

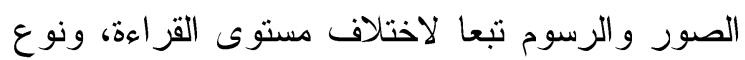
الموضوع، فتكثر في المستويات الأولى للقراءة، وتقل

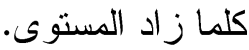

و. الألوان: يفضل معظم القراء الصور و الرسوم الملونة و إن كان من الناحية الفنية فإن أي صور غير الأسود

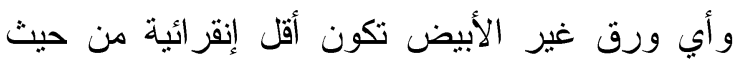
الطباعة، وترى بعض الدراسات إن الحبر الأسود

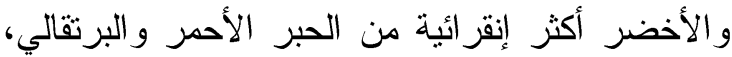
كما إن استخدام الحروف الكبيرة، والخطوط المائلة، و الأحبار مرة واحدة أو لأغراض مختلفة في الصفحة نفسها يؤدي إلى إرباك القارئ، وليس مساعدته على الإنى الفهم. ز. الطباعة: للطباعة دور كبير في مدى إنقرائية النص،

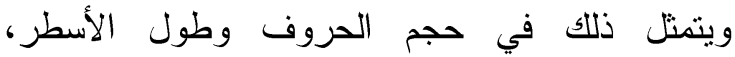


ץ-تأخذ طريقة إختبار كلوز فى الإعتبار العوامل المؤثرة

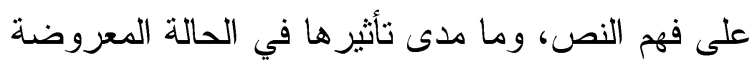
أمام القارىء.

ب-بتمبز بمرونته في إعداد نماذج متعددة من الإختبار للنص الواحد عن طريق تغيير الكلمات المحذوفة.

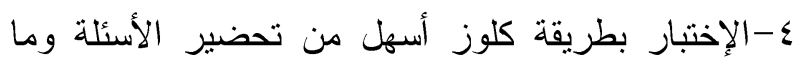
تحتوي عليه من مشاكل بالنسبة لنص السؤال، وإيجاد

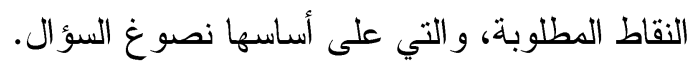
ويصنف القراء وفقا للإققرائية فى هذا الإختبار إلى ثلاثة مستويات هي:

1-المستوى المستقل: وهو المستوى الذي يستطيع عنده الثخص أن يقر أ النص ويستو عبه دون تلقي مساعدة من لـن المعلم، ويتحدد بحصول الثخص على درجة تقدر بين

$$
\text { (اب7-... (1\%) في إختبار كلوز. }
$$

ץ-المستوى النعليمي: هو المستوى الذي يستطيع الشخص

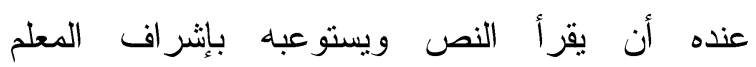
ومساعدته، ويتحدد بحصول الثخص على درجة تقدر

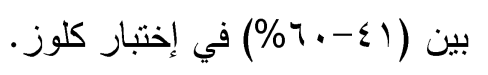

r-المسنوى الإحباطي: وهو المسنوى الذي يعجز عنده الثخص من استيعاب النص وفهمه حتى بمساعدة المعلم، ويتحدد بحصول الثخص على درجة أقل من بن

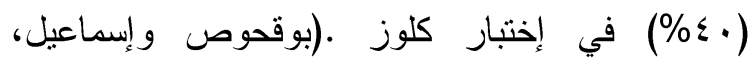

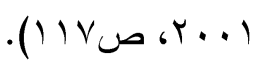

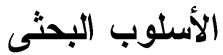

\section{المصطلحات البحثية:}

1. مجلة الإرشاد الزراعى: ويقصد بها فى هذا البحث،

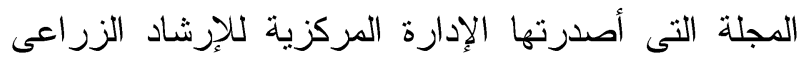

$$
\text { عدد سبتمبر عام 10 ب. r. }
$$

r. إنقرائية مجلة الإرشاد الزراعى: ويقصد بها فى هذا

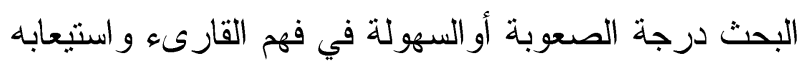

وعلى القراء معرفة الكلمات المحذوفة، ومحاولة استرجاع هذه الكلمات بصورة صحيحة، وتفيد نتيجة هذا الإختبار في

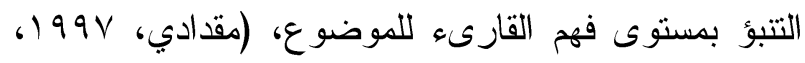

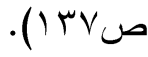
ويقيس إختبار كلوز (التتمة) ما يلى: (طعيمة، ومناع،

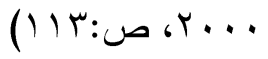
1- درجة الاتصال بين مرسل يكتب رسالة، ومستقبل يتلقى

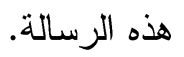
ץ- قدرة القارئ على فهم النص، وفهم الأجز اء التي ينكون منها. ب-ألفة القارئ بالتر اكيب العربية، بحيث يستطيع تحديد نوع الكلمة المحذوفة من خلال موضعها في الجملة.

$$
\text { ـ- الرصيد اللغوي عند (القارىء). }
$$

ج-الإملاء والخط، فملأ الفراغ بكلمات غريبة يكتبها الطالب يمكن عن طريقها قياس قدرته على كتابة الحرف العربي ومر اعاة شروط الصحة و التهجي. V- القدرة على التذكر و التعلم.

^-إتجاهات القراء، و التعرف على مواقفهم إزاء قضايا

$$
\text { معينة، أومفهومات محددة. }
$$

9-يقيس إختبار التتمة مستوى سهولة أوصعوبة النص، أى أى أنه يقيس إنقر ائية النص.

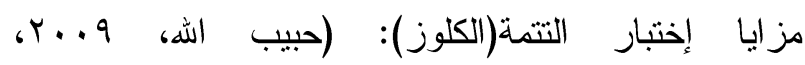
ص: (1)

1- تمتاز هذه الطريقة بدرجة صدق عالية بالنسبة لقياس فهم المقرو ء، فعن طريق الحذف يمكن معرفة الفهم العام حسب قدرة الممتحن في إكمال الكلمات الناقصة وليس على أساس فهم أسئلة. 
مجلة الإسكندرية للتبادل العلمى - (مجلد Tr العددء) أكتوبر - ديسمبر 1 ـ

مجالس إدارات سبع جمعيات تعاونية زر اعية تم اختيارها عشو ائيا، و البالغ عددهم خمسين مبحوثا. جمع وتحليل البيانات:

تم تصميم إختبار كلوز لإنقرائية مجلة الإرشاد

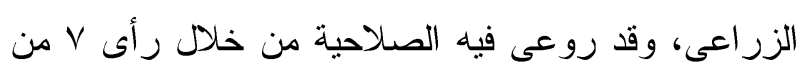

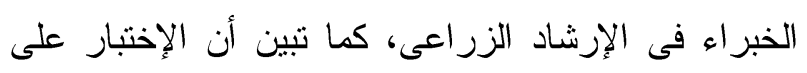
درجة عالية من الثبات، حيث بلغت قيمة معامل الثبات ^ر, • وقد نم استيفاء بيانات الإختبار، وبعض البيانات المتعلقة بخصائص المبحوثين من جميع أعضاء مجالس إدارات الجمعيات التعاونية الزراعية السبع المختارة عشوائيا. وقد استخدمت النسب المئوية، والجداول التكرارية، و المتوسط

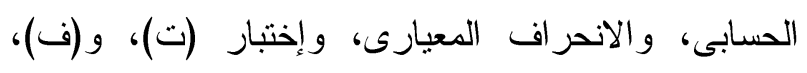

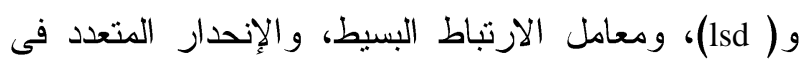

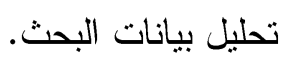

\section{النتائج البحثية}

أولا: الخصائص الثخصية المميزة للمبحوثين توضح النتائج البحثية الو اردة فى جدول ( () ما يلى: - أن جميع أعضـــاء مجـــالس إدارة الجمعيــات التعانيــة الزر اعية المبحوثين يقرؤون ويكتبون، وأن • (1) منهم

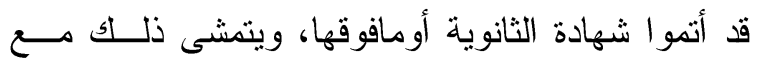

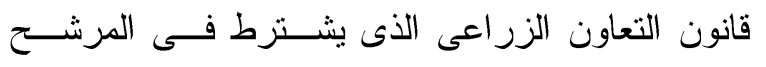

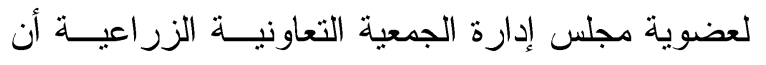
يكون ملما بالقر اعة و الكتابة.

- أن كV7\% من المبحوثين تقل حياز اتهم الأرضية الزراعية عن بح قير اط.

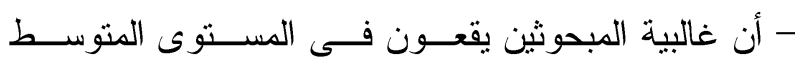

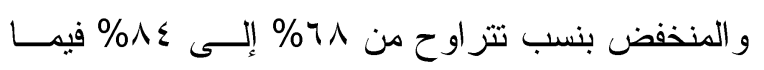
يختص بكل من: الوعى العام، و الإســـهام و المشــــاركة

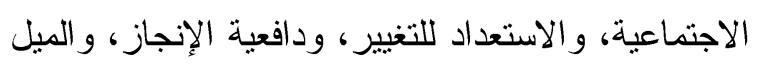

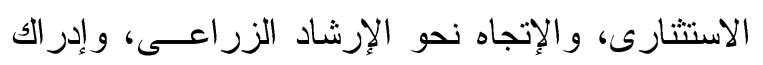

لخمسة موضوعات تمنل المضمون الرئيسى فى مجلة الإزشاد الزراعى وهى: المحاصيل الحقلية، ومحاصيل الخضر، وأثجار الفاكهة، و والإنتاج الحيو انى، و والإنتاج الداجنى، ويتم التعبير عنها بدرجات يتم التوصل إليها من خلال استجابات الزراع المبحوثين لإختبار كلوز (التتمة)، حيث تم حذف . r كلمة من النص المختار فى كل موضوع، وفقا لشروط إختبار كلوز، وطلب من كل مبحوث هن هن استيفاء نفس الكلمة التى تم حذفها من النص الأصلى للموضوع، أو بكلمة أخرى تؤدى نفس المعنى، بغض النظر عن صحتها الإملائية، ويعطى المبحوث درجة واحدة لكل كلمة صحيحة، وبذللك تزاوحت الدرجات الكلية التى يمكن أن يحصل عليها المبحوث فى الإختبار من (صفر--.. درجة)، حيث يختص كل موضوع بقيم تنز اوح من (صفر إلى • r درجة). وقد نم تحويل الدرجات التى يحصل عليها المبحوثون إلى نسب مئوية، لتتشى مع النسب المئوية لمستويات إختبار كلوز المتغير ات البحثية: المتغيرات المستقلة: وهى: المستوى التعليمى للمبحوثين،

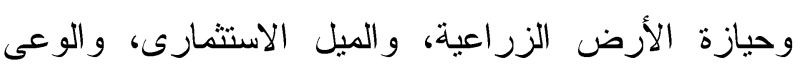

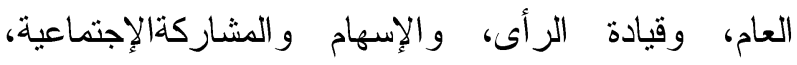

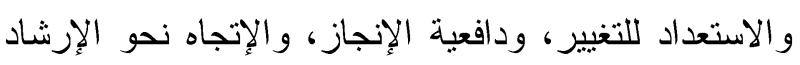

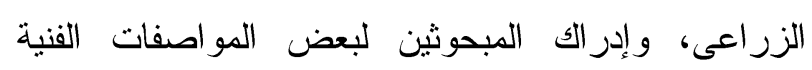
و التعليمية لمجلة الإرشاد الزراعى واعى.

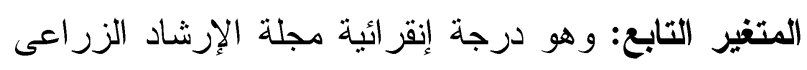
بين أعضاء مجالس إدارات الجمعيات التعاونية الزراعية التراته المبحوثين.

الشاملة و العينة:

تمثلت شاملة البحث فى جميع أعضاء مجالس إدارات الجميات التعاونية الزر اعية التابعة للائتمان الزر اعى بمركز إيتاى البارود بمحافظة البحيرة و البالغ عددها 10 جمعية تعاونية زراعية، وتمثلت عينة البحث فى جميع أعضاء 
(1) مستوى إنقرائية مجلة الإرشاد الزراعى:

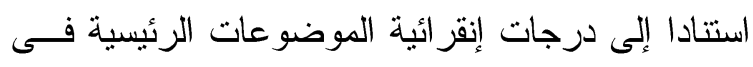

مجلة الإرشاد الزراعى مجتمعة وفقا لإختبار كلوز فقد تبين

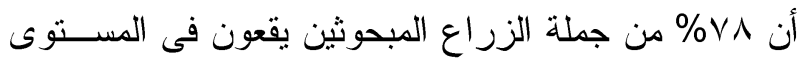

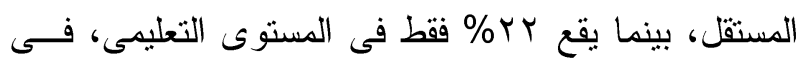

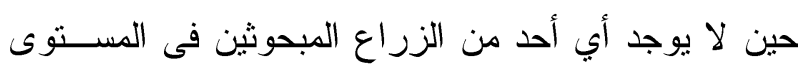

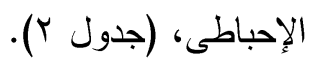

المبحوثين لبعض المواصفات الفنية و التعليميــة لمجلـــة

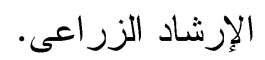

ثناتيا: إنقرائية مجلة الإرشاد الزراعى:

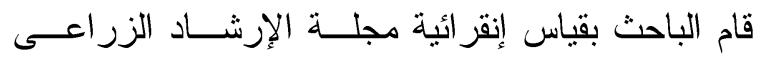

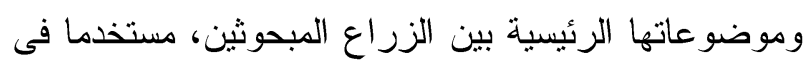

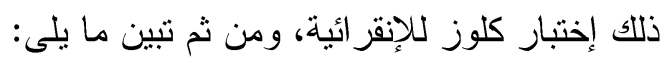

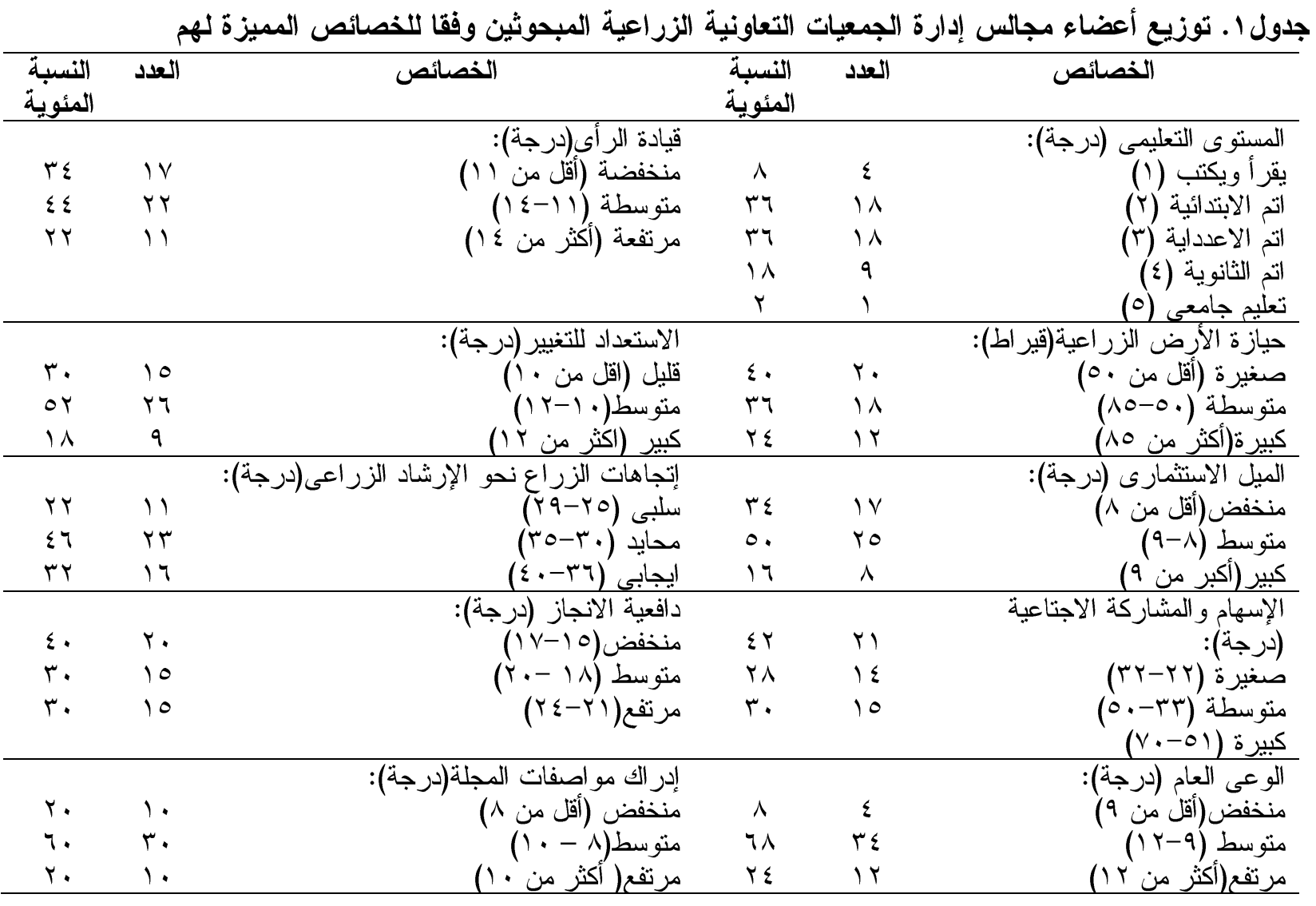

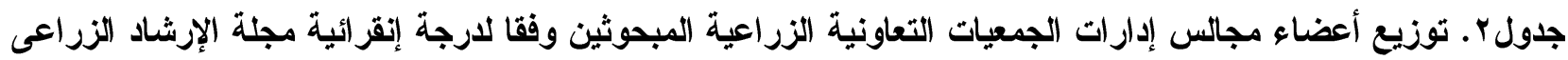

\begin{tabular}{|c|c|c|c|c|c|c|}
\hline الإحر اف المعيارى & المتوسط الحسابي & أكبر قيمة & أصغر قيمة & النسبة المئوية & العدد & مستوى الإققرائية \\
\hline \multirow{5}{*}{$10, r$} & \multirow{5}{*}{$\mathrm{v} 0, \mathrm{~V}$} & \multirow{5}{*}{$1 \ldots$} & \multirow{5}{*}{0.} & . & . & (. المستوى درجة فأحباطل) \\
\hline & & & & TY & 11 & المستوى التعليمى \\
\hline & & & & & & (1) - (7) \\
\hline & & & & $\vee \wedge$ & ra & المستوى المستقل \\
\hline & & & & $1 \ldots$ & 0. & المجموع \\
\hline
\end{tabular}


المبحوثين، حيث يستطيع ، ر\% منهم الاعتماد على أنفسهم فى قر اعة المجلة، و الاستفادة منها دون مساعدة من المرشد الزراعى أوغيره فى فهم موضوعات المجلة، بينما يحتاج \%r. توضيح وتعليم موضوعات المجلة حتى يمكنهم الاستفادة منها.

وتوضح بيانات نفس الجدول أن منوسط الإنقرائية قد

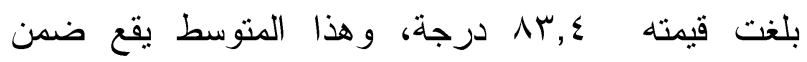
المستوى المستقل فى إختبار كلوز للإنقرائية، الأمر الذى لإه يؤكد سهولة ومناسبة موضوعات محاصيل الحقل الواردة فى مجلة الإرشاد الزر اعى لجميع المبحوثين، وهذه النتائج تتفق مع المنطق الإرشادى والقانون الذى يشترط إجادة القراعة والكتابة فى من يترشح لعضوية مجلس إدارة الجمعية التعاونية الزر اعية.

\section{ب) مستوى إنقرائية موضوعات محاصيل الخضر :}

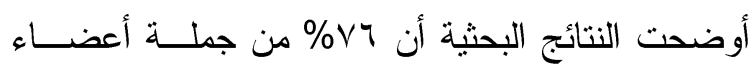
مجالس إدارات الجمعيات التعاونية الزر اعيــة المبحــــثـين يقعون فى المستوى المستقل، ويقع ؟r\% فقط فى المستوى التعليمى، فى حين لا يوجد أي أحد من الزراع المبحوثين

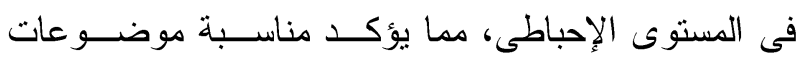
محاصيل الخضر التى تتاولتها مجلة الإرشاد الزراع لجميع المبحوثين، حيث يستطيع VVT\% منهم على أنفسهم فى قر اءة

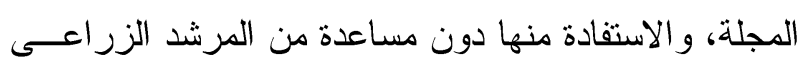

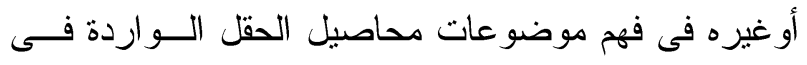

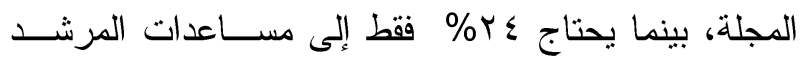

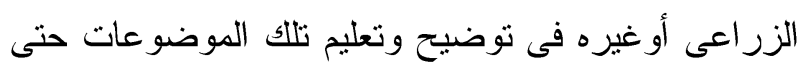

يمكنه الاستفادة منها.

وتوضـح بيانات نفس الجدول أن متوسط الإنقرائية قـــ

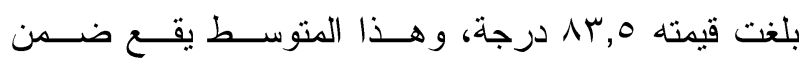

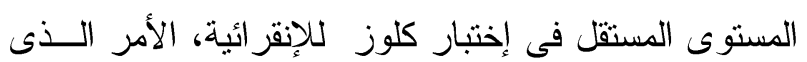

مما سبق يتضح مناسبة الموضو عات الرئيسية المدروسة

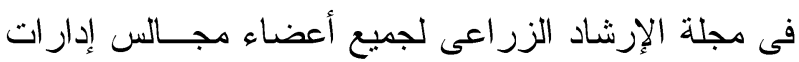

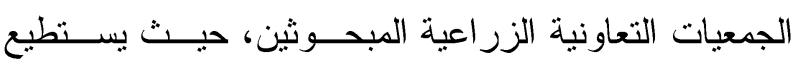

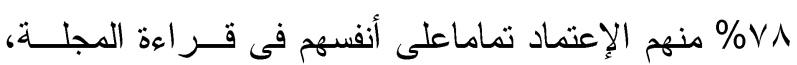
والاستفادة منها دون مساعدة من المرشد الزر اعى أو غيره

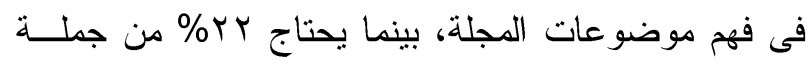
المبحوثين فقط إلى مساعدات المرشد الزر اعى، أو غيــره من المعنيين بالثئون الزراعية ممن يثق فيهم وفى قدر اتهم

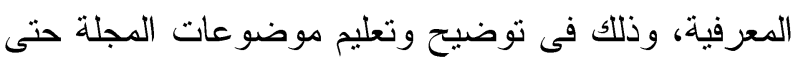
يمكنهم فهمها و الاستفادة منها. وتوضـح بيانات نفس الجدول أن متوسط الإنقز ائية قــــ بلغت قيمته VO,V درجة، وهذا المتوسط يقع ضمن المستو

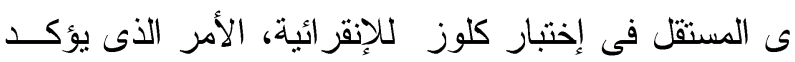
سهولة ومناسبة المجلة بصفة عامة لجميع أعضاء مجــالس

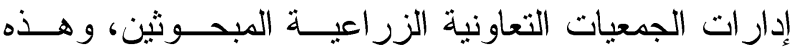
النتائج تتفق مع المنطق الإرشـادى و القانون الــذى يثـــرط إجادة القراءة و الكتابة فى من يترشح لعضوية مجلس إدارة الجمعية التعاونية الزر اعية.

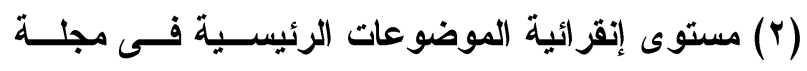

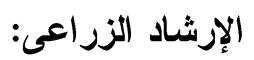

بدر اسة إنقر ائية موضوعات مجلة الإرشاد الزر اعى كل

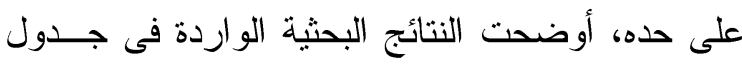

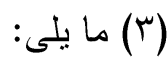

أ) مستوى إنقر ائية موضوعات المحاصيل الحقلية: أوضحت النتائج البحثية أن .ی^\% من جملة أعضاء مجالس إدارات الجمعيات التعاونية الزراعية المبحوثين

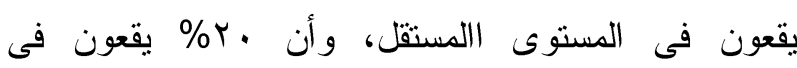

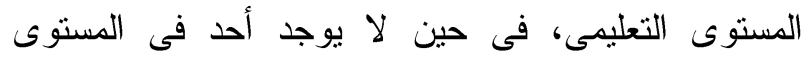
الإحباطى. مما بؤكد مناسبة موضوعات محاصبل الحقل التى تناولتها مجلة الإرشاد الزراعى لجميع الزراع 
التعليمى، فى حين لا يوجد أبي أحد من الزراع المبحوثين

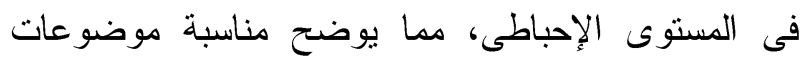

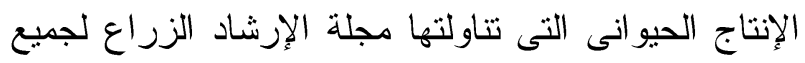
المبحوثين، حيث يستطيع ؟ ؟\% منهم على أنفسهم فى قر اءة

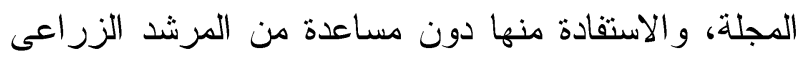

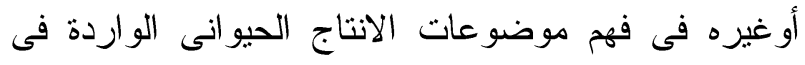

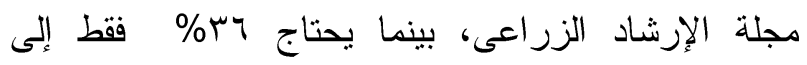

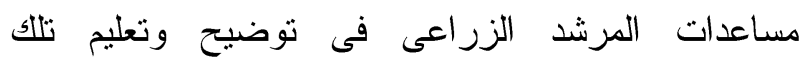
الموضو عات، حتى يمكنه الإستفادة منها. وتوضح بيانات نفس الجدول أن متوسط الإنقرائية قد بلغت قيمته 79 درجة، و هذا المتوسط يقع ضمن المستوى المستقل فى إختبار كلوز للإنقرائية، الأمر الذى يؤكد سهولة ومناسبة موضوعات الإنتاج الحيوانى الواردة فى مجلة الإرشاد الزراعى لجميع المبحوثين، وهذه النتائج تتفق

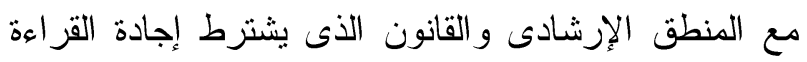
والكتابة فى من يترشح لعضوية مجلس إدارة الجمعية التعاونية الزر اعية.

0) مستوى إنقرائية موضوعات الإتتاج الاجنى: أوضحت النتائج البحثية أن ^ء\% من جملة أعضاء مجالس إدارات الجمعيات التعاونية الزراعية المبحوثين يقعون فى المستوى المستقل، ويقع ro\% فقط فى المستوى التعليمى، فى حين لا يوجد أب أحد من الزراع المبحوثين فى المستوى الإحباطى، مما يوضح مناسبة موضوعات الانتاج الداجنى التى تتاولتها مجلة الإرشاد الزراع لجميع المبحوثين، حيث يستطيع ^^؛ م منهم الاعتماد على أنفسه فى قر اعة المجلة، والإستفادة منها دون مساعدة من المرشد الزراعى أوغيره فى فهم موضوعات الإنتاج الداجنى

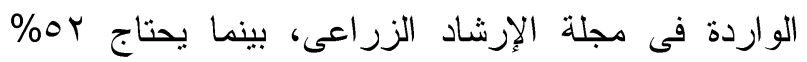
فقط إلى مساعدات المرشد الزر اعى فى توضيح وتعليم تلاكت الموضو عات، حتى يمكنه الإستفادة منها.
يؤكد سهولة ومناسبة موضوعات محاصبل الخضر الواردة فى مجلة الإرشاد الزر اعى لجميع المبحوثين، وهذه النتــائج تتفق مع المنطق الإرشادى والقانون الذى يشــترط إجــادة

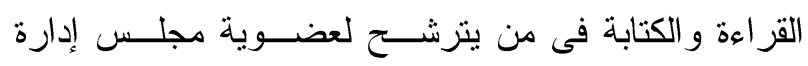
الجمعية التعاونية الزر اعية.

ج) مستوى إنقر ائية موضوعات المحاصيل الفاكهة: أوضحت النتائج البحثية أن ب^\% من جملة أعضاء مجالس إدارات الجمعيات التعاونية الزراعية المبحوثين يقعون فى المستوى المستقل، ويقع rس\% فقط فى المستوى التعليمى، فى حين لا يوجد أبي أحد من الزراع المبحوثين فى المستوى الإحباطى، مما يوضح مناسبة موضوعات محاصيل الفاكهة التى تناولتها مجلة الإرشاد الزراع لجميع المبحوثين، حيث يستطيع ب\%\% منهم على أنفسهر فى قر اعة

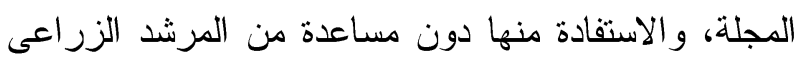

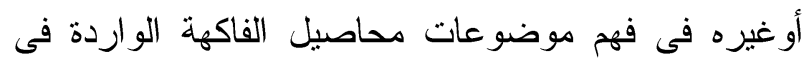
مجلة الإرشاد الزراعى، بينما يحتاج rr\% فقط هو إلى

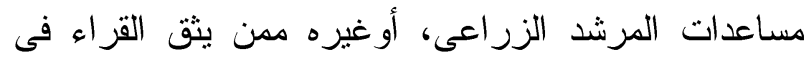
قدراتهم المعرفية الزراعية، في توضيح وتعليم تللك الموضو عات حتى يمكنهم الاستفادة منها.

وتوضح بيانات نفس الجدول أن متوسط الإنقرائية قد بلغت قيمته VT درجة، وهذا المتوسط يقع ضمن المستوى المستقل فى إختبار كلوز للإنقر ائية، الأمر الذى يؤكد سهولة ومناسبة موضوعات المحاصيل الفاكهة الواردة فى مجلة الإرشاد الزراعى لجميع المبحوثين، وهذه النتائج تتقق مع المنطق الإرشادى والقانون الذى يشترط إجادة القراعة و الكتابة فى من يترشح لعضوية مجلس إدارة الجمعية التعاونية الزر اعية. د) مستوى إنقرائية موضوعات الإتتاج الحيوانى:

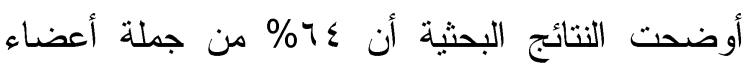
مجالس إدارات الجمعيات التعاونية الزراعية المبحوثين يقعون فى المستوى المستقل، ويقع بس\% فقط فى المستوى 
جدول r. توزيع المبحوثين وفقا لمستويات إنقرائية موضوعات مجلة الإرشاد الزراعى

\begin{tabular}{|c|c|c|c|c|c|c|}
\hline الإحر اف المعيارى & المتوسط & \multirow{2}{*}{\multicolumn{4}{|c|}{ أولا: إنقرائية موضوعات الححاصيل الحقلية }} & مستوى الإققر ائية \\
\hline & \multirow{4}{*}{$\Lambda r, 0$} & & & & & \\
\hline \multirow{3}{*}{10,19} & & & & $\dot{r}$ & ir & المستوى الاحباطى (• ؛ درجة فأقلى) \\
\hline & & $1 \ldots$ & $\circ$. & $\begin{array}{ll}T \varepsilon \\
V y\end{array}$ & ri & المستوى المستقلى (ابح درجة فأكثر) \\
\hline & & & & $1 \ldots$ & 0. & 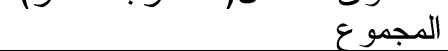 \\
\hline \multirow{4}{*}{$1 \leq, Y \Psi$} & \multicolumn{5}{|c|}{ ثانيا: إنقرائية موضوعات محاصيل الخضر } & \\
\hline & & & & $\dot{r}$. & 1. & 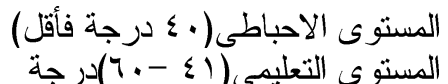 \\
\hline & $\Lambda \Gamma, \Upsilon \wedge$ & $1 \cdots$ & 0. & ᄉ. & $\varepsilon$. & المستوى المستقل (آ درجة فأكثر) \\
\hline & & & & $\ldots$ & 0. & 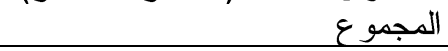 \\
\hline \multirow{5}{*}{$19, Y \varepsilon$} & \multicolumn{5}{|c|}{ ثالثا: إنقر ائية موضوعات الفاكهة } & \\
\hline & & & & . & . & المستوى الاحباطى(• ؛ درجة فأقل) \\
\hline & $V_{7}$ & & $\leqslant 0$ & rr & 19 & المستوى التعليه \\
\hline & & $1 \ldots$ & 20 & 41 & $r \varepsilon$ & المستوى المستقل (آ درجة فأكثر) \\
\hline & \multirow{2}{*}{\multicolumn{5}{|c|}{ رابعا: إنقرائية موضوعات الإنتاج الحيوانى }} & المجموع ع \\
\hline \multirow{4}{*}{$17, Y Y$} & & & & & & \\
\hline & & & & & & المستوى الاحباطى(· ؛ درجة فأقل) \\
\hline & 79 & $1 \ldots$ & $\leqslant 0$ & ry & in & المستوى التعليمى(1) \\
\hline & & & & $1 \ldots$ & 0. & 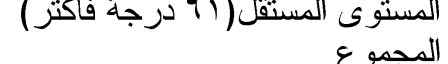 \\
\hline \multirow{4}{*}{17.71} & \multicolumn{5}{|c|}{ خامسا: إنقرائية موضوعات الإتتاج الداجنى } & \\
\hline & & & & or & iq & 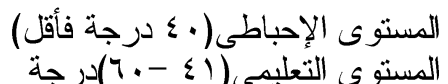 \\
\hline & $70, r$ & $1 \ldots$ & $\leqslant 0$ & $\varepsilon \wedge$ & $r \varepsilon$ & المستوى المستقل (اب درجة فأكثر ) \\
\hline & & & & $1 \ldots$ & 0. & 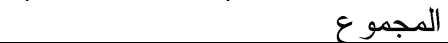 \\
\hline
\end{tabular}

الإنتاج الحيوانى، وأخيرا موضوعات الإنتاج الداجنى،

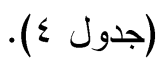

ثالثا: الفروق بين متوسطات درجات إنقرائية موضوعات

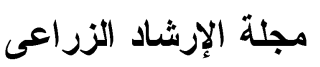

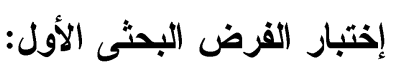

اتضح من دراسة الفروق بين متوسطات درجات إنقر ائية موضوعات مجلة الإرشاد الزراعى المدروسة بين

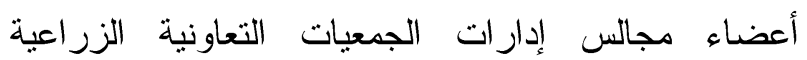
المبحوثين، وذلك باستخدام إختبار ف لتحليل التباين بين تلك التكات

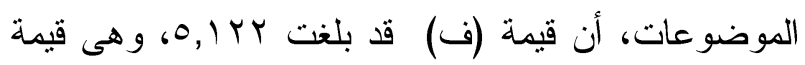

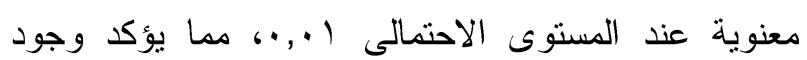
فروق معنوية بين متوسطات مستوى إنقر ائية الموضوعات بلهات الخمسة المدروسة. وعلى ذلك تم رفض الفرض الصفرى،
وتوضح بيانات نفس الجدول أن متوسط الإنقرائية قد

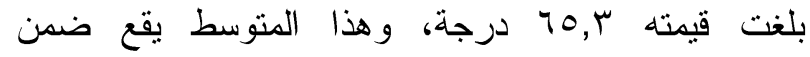
المستوى المستقل فى إختبار كلوز للإنقرائية، الأمر الذى

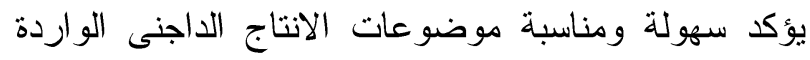
فى مجلة الإرشاد الزراعى لجميع المبحوثين، وهذه النتائج تتفق مع المنطق الإرشادى والقانون الذى يشترط إجادة الإداد القراءة والكتابة فى من يترشح لعضوية مجلس إدارة الجمعية التعاونية الزر اعية. - الجية وقد أمكن ترتيب موضوعات مجلة الإرشاد الزراعى تنازليا وفقا لمتوسط إنقرائية كل منها على النحو التالى: موضوعات محاصيل الحقل، يليها موضوعات محاصيل الخضر ، ثم موضوعات محاصيل الفاكهة، ثم موضو عات 
جدول ع. ترتيب موضوعات مجلة الإرشاد الزراعى وفقا للمتوسط الحسابى لارجات إنقرائيتها بين أعضاء مجالس إدارات الجمعيات التعاونية الزراعية المبحوثين

\begin{tabular}{|c|c|c|c|}
\hline ترتيب الموضوعات وفقا لإقتر ائيتها & الإحر اف المعيارى & المتوسط \% & موضوعات مجلة الإرشاد الزراعى \\
\hline 1 & 10,19 & $\Delta r, 0$ & محاصيل الحقل \\
\hline r & $1 \varepsilon, Y q$ & $\Lambda \Gamma, \Gamma \wedge$ & محاصيل الخضر \\
\hline س & $19, Y \leqslant$ & VY & محاصيل الفاكهة \\
\hline$\varepsilon$ & $17, Y Y$ & 79 & الإنتاج الحيو اني \\
\hline 0 & 17,71 & $70, r$ & الإنتاج الداجنى \\
\hline
\end{tabular}

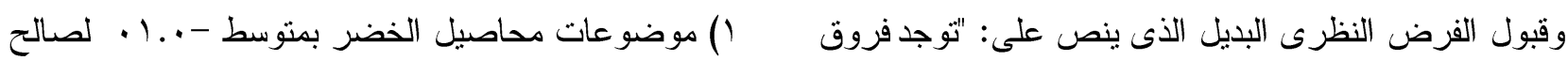

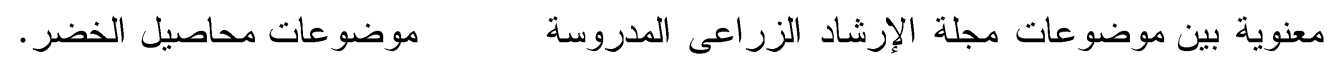
r r موضوعات أشجار الفاكهة بمتوسط قدره 9 , • لصالح وفقا لمتوسط درجات إنقر ائيتها". ولتحديد دلالات الفروق بين الموضوعات المدروسة من موضوعات المحاصيل الحقلية.

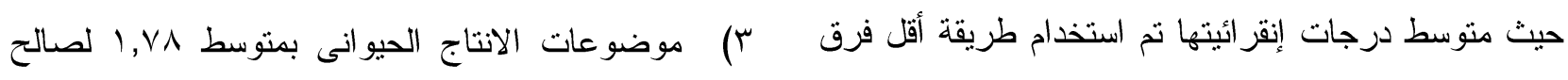
موضو عات المحاصيل الحقلية. معنوى (L S D) ) و وتبين ما يلى (جدوله). §) وموضوعات الإنتاج الداجنى بمتوسط ب,Y، لصالح موضو عات المحاصيل الحقلية. أولا: توجد فروق معنوىة بين متوسط درجات إنقرائية

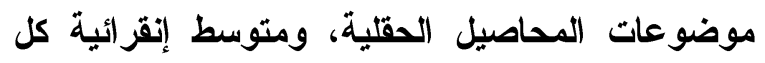
من:

جدول ه. نتائج طريقة أقل فرق معنوى لإتجاهات الفروق بين الموضوعات المدروسة وفقا لمتوسطات درجات الإقرائية

\begin{tabular}{|c|c|c|c|c|c|}
\hline مستوى 09\% & فترة الثقة & \multirow{2}{*}{ متّوسط الفرق } & \multirow{2}{*}{ المتغيرات الداخلة فى التفاعل } & \multirow{2}{*}{ الموضوروسة } & \multirow{2}{*}{ المتغير ات } \\
\hline حـ اعلى & حد ادنى & & & & \\
\hline $1, Y V V$ & $1, Y \vee V-$ & $\cdot, \cdot 1$ & موضو عات محاصيل الخضر & موضو عات & متوسط الإنقر ائية \\
\hline$r, I V V$ & $\cdot, r \vee V-$ & $\cdot, 9$ & موضوعات أشجار الفاكهة & المحاصيل الحقلية & \\
\hline $\mathrm{r}, .0 \mathrm{~V}$ & $\cdot, 0 . r$ & $* 1, \vee \wedge$ & موضو عات الإنتاج الحيوانى & & \\
\hline r,oVV & מזr. & $* r, r$ & موضو عات الإنتاج الداجنى & & \\
\hline $1, Y V V$ & $1, Y \vee V-$ & $\cdot, \cdot 1-$ & موضوعات المحاصيل الحقلية & موضو عات & \\
\hline Y,IVV & $\cdot, \Gamma \vee V-$ & $\cdot, 9$ & موضوعات أثجار الفاكهة & محاصبل الخضر & \\
\hline $\mathrm{r}, .0 \mathrm{~V}$ & $\cdot, 0 \cdot r$ & $* 1, \vee \wedge$ & موضو عات الانتاج الحيو انى & & \\
\hline r,oVV & מזr & $* r, r$ & موضو عات الإنتاج الداجني & & \\
\hline$\cdot, r V V$ & Y,IVV- & $\cdot, 9-$ & موضو عات المحاصيل الحقلية & موضو عات أنشجار & \\
\hline$\cdot, \mu \vee v$ & $r, I V V-$ & $\cdot, 9-$ & موضو عات محاصيل الخضر" & الفاكهة & \\
\hline r,10V & $\cdot, r q \vee-$ & $\cdot, \wedge \wedge$ & موضو عات الإنتاج الحيو انى & & \\
\hline$r, T \vee V$ & سזו, & $* 1, \varepsilon$ & موضو عات الإنتاج الداجنى & & \\
\hline$\cdot, 0 . r-$ & $r, .0 V-$ & $* 1, \vee \wedge-$ & موضو عات محاصيل الحقل & موضو عات الإنتاج & \\
\hline$\cdot, 0 . r-$ & $r, .0 V-$ & $* 1, \vee \wedge-$ & موضو عات محاصيل الخضر & 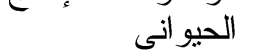 & \\
\hline קצח, & $r, 10 V-$ & $\cdot, \wedge \wedge-$ & موضوعات أثنجار الفاكهة & & \\
\hline $1, \vee 99$ & $\cdot, \mathrm{V} O \mathrm{~V}-$ &., $0 Y$ & موضوعات الإتتاج الداجنى & & \\
\hline I, Or- & r,ovV - & $* r, r-$ & موضوعات المحاصيل الحقلية & موضو عات الإنتاج & \\
\hline $1, \cdot r r-$ & $r, O V V-$ & $* r, r-$ & موضو عات محاصيل الخضر & الداجنى & \\
\hline - & $r, T \vee V-$ & $* 1, \varepsilon-$ & موضوعات أثنجار الفاكهة & & \\
\hline$\cdot, \mathrm{V} O \mathrm{~V}$ & $1, \vee 9 \vee-$ &., OY - & موضو عات الإنتاج الحيو انى & & \\
\hline
\end{tabular}


(1)(العلاقات الارتباطية بين كل من المتغيرات المستقلة ودرجة إنقرائية مجلة الإرشاد الزراعى بين أعضاء

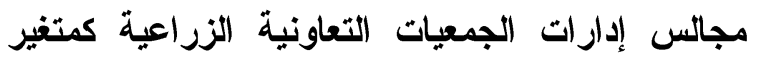

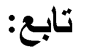
تم دراسة العلاقات الإرتباطية بين المتغيرات المستقلة،

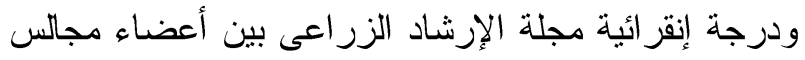

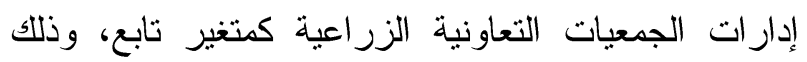

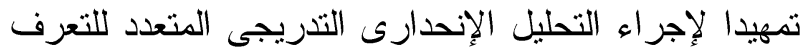

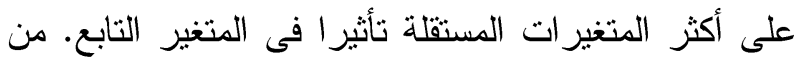
ثم تبين قيام علاقة إرتباطية موجبة ومعنوية عند المستوى الاحتمالى ا.,.• بين المتغير التابع وكل من المتغيرات المستقلة الآتية: المستوى التعليمى للمبحوثين، و والديل الاستثمارى، و الوعى العام، ودافعية الإنجاز ، والإتجاه نحو

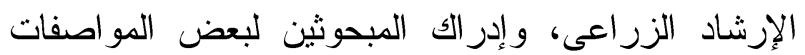
الفنية والتعليمية لمجلة الإرشاد الزراعى، فى حين كانت

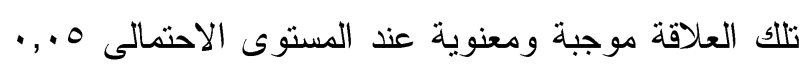

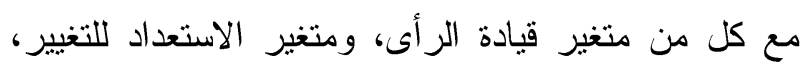
بينما كانت نلاك العلاقة عكسية ومعنوية عن المستوى الاحتمالى ه.,. الزراعية، ومتغير الإنهام و والمشاركة الاجتماعية.

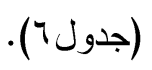

مما سبق يتضح معنوية العلاقات الارتباطية بين جميـع المتغيرات المستقلة المدروسة كل على حده ودرجة إنقر ائية مجلة الإرشاد الزر اعى بين الزراع المبحوثين كمتغير تابع.
ثانيا: توجد فروق معنوية بين متوسط درجات إنقرائية موضوعات محاصيل الخضر، ومتوسط إنقرائية

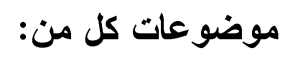

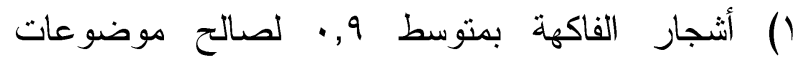

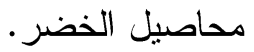
r) الإنتاج الحيوانى بمتوسط قدره Y, 1, لصالح موضوعات محاصيل الخضر .

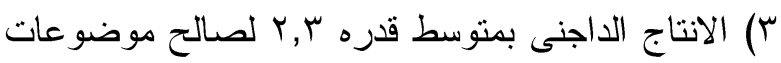

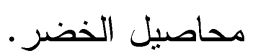

ثثاثثا: توجد فروق معنوية بين متوسط درجات إنقرائية موضوعات أثجار الفاكهة، ومتوسط إنقرائية

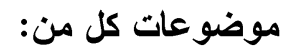

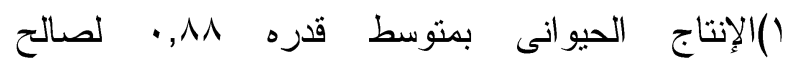
موضوعات أثنجار الفاكهة.

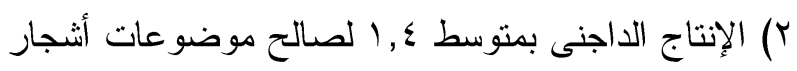
الفاكهة

رابعا: توجد فروق معنوية بين متوسط درجات إنقرائية

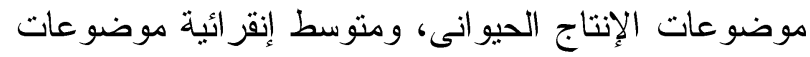
الإنتاج الداجنى، بمتوسط ب or, · لصالح موضوعات الصات الإنتاج

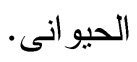

رابعا: المنغيرات المرتبطة والمؤثرة فى درجة إنقرائية

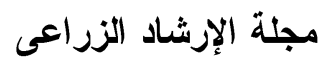
إختبار القرض البحثى الثانى:

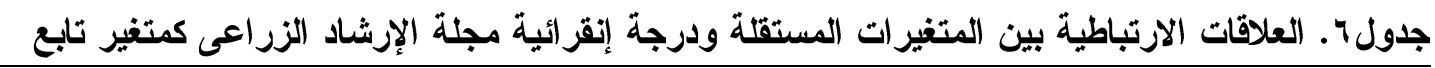

\begin{tabular}{|c|c|c|c|c|c|}
\hline المعنوية & الارتباط & المتغير & المعنوية & الارتباط & المتغير \\
\hline$\cdot, .0$ & . OTY & 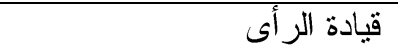 & $\cdot, ., 1$ & $\cdot, \lambda \cdot 9$ & المستوى التعليمى للمبحوث \\
\hline$\cdot, \cdot 1$ &., $0 \wedge \pi$ & دأفعية الانجاز & $\cdot, .1$ & ., Ү৭४ & حيازة الآرض الزراعية \\
\hline$\cdot, ., 1$ & .094 & الاتجاه نحو الإرشاد الزر اعى & $\cdot, \cdot 1$ & . & الإسهاج و المشاركة الاجتماعية \\
\hline$\cdots, .0$ & ., YqV & الاستعداد للتنغيير & $\cdot, .1$ & $\cdot, 097$ & الؤعى العام \\
\hline., .1 &., 190 & إدر اك مو اصفات مجلة الإرشاد &., .1 & $\cdot, \vee \vee 90$ & الميل الاستثماري \\
\hline
\end{tabular}


إدارات الجمعيات التعاونية الزر اعية المبحوثين كمتغير تابع بكل من المتغيرات المســقلة الآتيــة: المســتوى

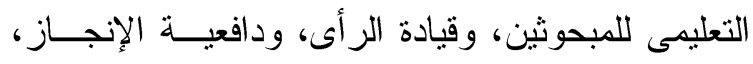

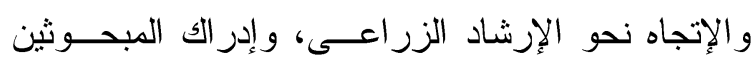

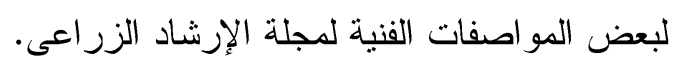
ولكى يتعرف الباحث على أكثر المتغيـرات المســتقلة

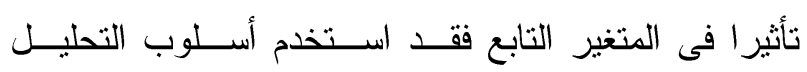
الإنحدارى المتعدد التدريجى بالإضافة، وقد أوضحت النتائج المبينة فى جدول (V) ما يلى: الخطوه الأولى: اشتملت الدالة على متغير مستقل واحد

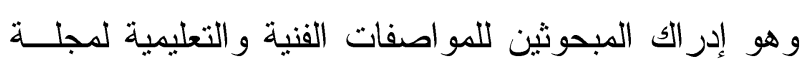
الإزشاد الزر اعى، وقد تبين أن هذا المتغير مسئول بمفــرده عن تفسير ب, •^^\% من التباين الممكن حدوثه فى المتغيـر

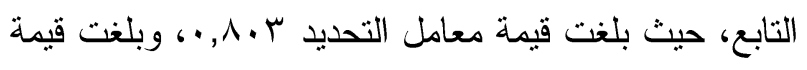

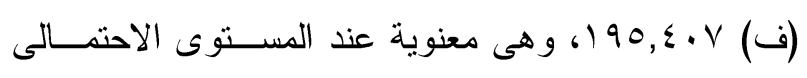

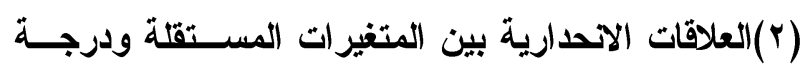

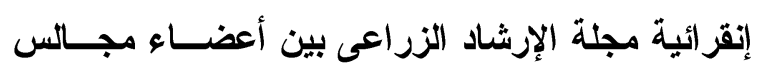
إدارات الجمعيات التعاونية الزراعية كمتغير تابع:

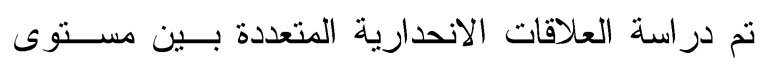

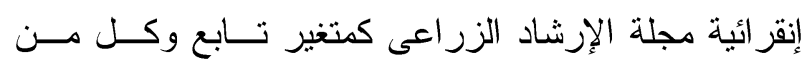

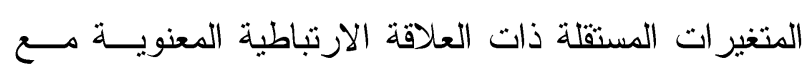

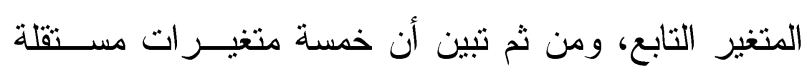

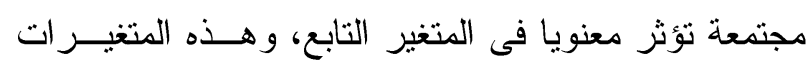

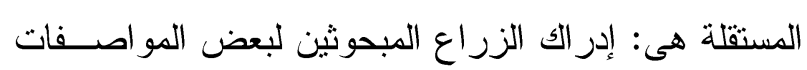

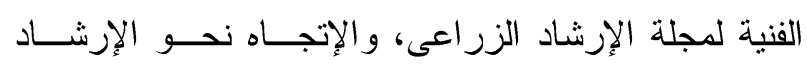

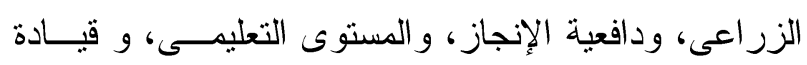

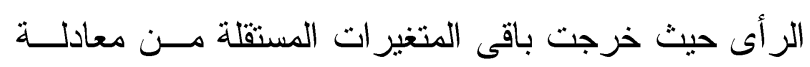
الانحدار.

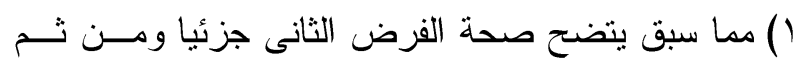

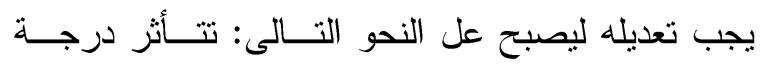

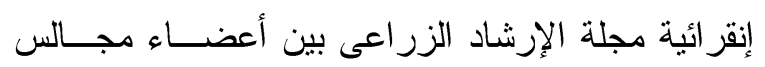

\begin{tabular}{|c|c|c|c|c|c|c|c|}
\hline مستوى معنوية & ف & נر & المعنوية & 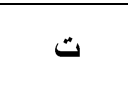 & معامل الآحدار & النموذج & الخطوة \\
\hline$\cdot, \cdot 1$ & $190, \varepsilon \cdot V$ & $\cdot, \wedge \cdot \Gamma$ & $\cdot, \cdot 1$ & $0 \leqslant 0 .-$ & $\begin{array}{l}r, 11 V- \\
V, r q \leq\end{array}$ & ثابر الك مو اصفات المجلة & 1 \\
\hline$\cdot, \cdot 1$ & $I V T, \wedge \leq 0$ & $\cdot, \wedge \wedge 1$ & $\begin{array}{l}., .1 \\
\cdot,+1 \\
., .1 \\
\end{array}$ & $\begin{array}{l}r, A Y I- \\
9,10 r \\
0,00 r\end{array}$ & $\begin{array}{l}\text { rI, rTO- } \\
0,10 Y \\
1, \text { rog }\end{array}$ & ألإبرابت مو اصفات المجلة & $r$ \\
\hline$\cdot, \cdot 1$ & $\mid V \varepsilon, \varepsilon \cdot \Lambda$ &., 919 & $\begin{array}{l}.,+1 \\
.,+1 \\
.,+1 \\
.,+1\end{array}$ & $\begin{array}{l}0, V Y q- \\
0, Y 19 \\
\varepsilon, \wedge \varepsilon Y \\
\varepsilon, Y T Y\end{array}$ & $\begin{array}{l}r V, T 11- \\
r, r \wedge 0 \\
\cdot, 94 \leq \\
1,104\end{array}$ & 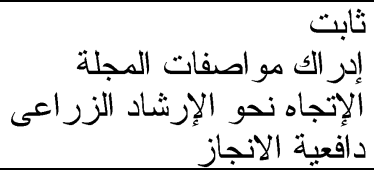 & $r$ \\
\hline$\cdot, \cdot 1$ & 171,194 & $\cdot, 9+0$ & $\begin{array}{l}\cdot,+1 \\
\cdot,+1 \\
\cdot,+1 \\
\cdot, \cdot 1 \\
\cdot,+1\end{array}$ & $\begin{array}{l}r, q 0 r- \\
\varepsilon, q 11 \\
0, \varepsilon \cdot r \\
r, r, r \\
r, r \vee v \\
\end{array}$ & $\begin{array}{l}19, v \leqslant- \\
r, 119 \\
\cdot, 9 \vee v \\
1,419 \\
r, .19\end{array}$ & 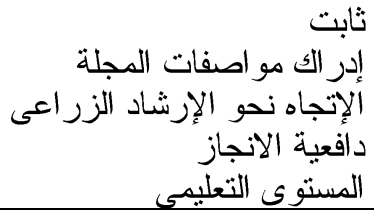 & $\varepsilon$ \\
\hline$\cdot, \cdot 1$ & $1 \% q, 0 \leqslant 1$ & $\cdot, 9 \leqslant 1$ & $\begin{array}{l}\cdot,+1 \\
\cdot,+1 \\
\cdot,+1 \\
\cdot,+1 \\
\cdot,+1 \\
.,+1\end{array}$ & $\begin{array}{l}r, 00 Y- \\
\varepsilon, \cdot r \\
\varepsilon, H \\
r, T r \\
r, 0 Y \Lambda \\
r, .90\end{array}$ & $\begin{array}{l}1 \varepsilon, \cdot 1 \Lambda- \\
r, r \vee q \\
\cdot, \vee 9 \Lambda \\
1, \cdot v \\
r, 1 \leqslant 1 \\
\cdot, \wedge \cdot 9 \\
\end{array}$ & 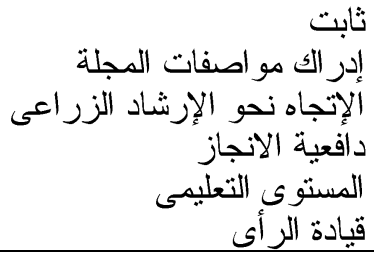 & 0 \\
\hline
\end{tabular}




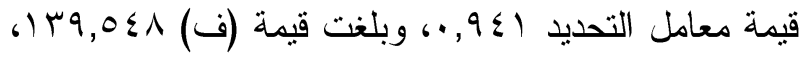
وهى قيمة معنوية عند المستوى الاحتمالى ا +, •.

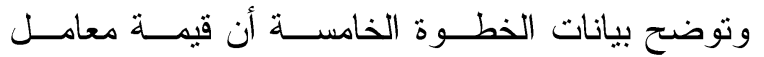
الإنحدار الجزئى لمتغير إدراك المبحوثين لخصـائص مجلـــة

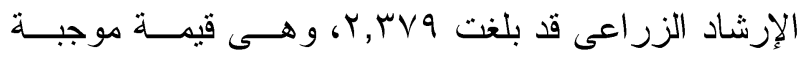
تعكس قيام علاقة انحدارية معنوية عند المستوى الإحتمالى الإلى

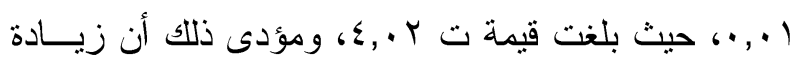
قيادة الر أى كمتغير مستقل بمقدار درجة واحـدة، يترتــب

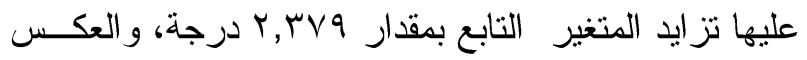

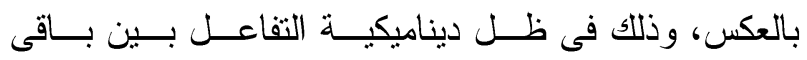
المتغير ات المستقلة المتضمنة فى النموذج. ويلاحظ من البيانات الخاصة بهذا النمــوذج أن أكثــر المتغير ات المستقلة تأثنير ا فى فى درجة إنقر ائيــة أعضـــــاء

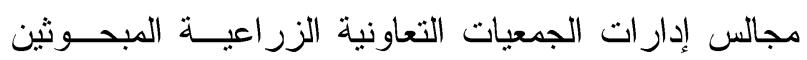
كتغير تابع هو : إدر الك الزراع المبحوثين للمو اصفات الفنية

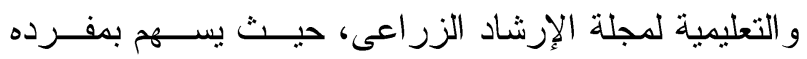
بتقسير نسبة r, •^\% من التباين الممكن حدوثه فى المتغير التابع، يليه متغير الإتجاه نحو الإرشاد الزراعى الذى يفسر \% \%,^

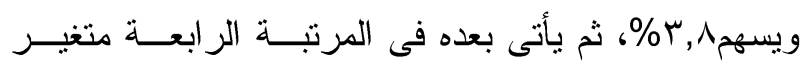

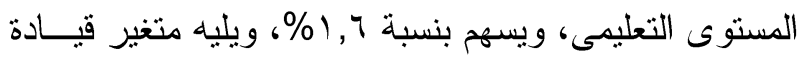
الر أى الذى يسهح بنحو 7, • \% من التباين الممكن حدوثه فى

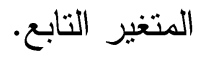

\section{المـــراجـع}

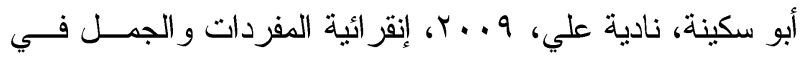

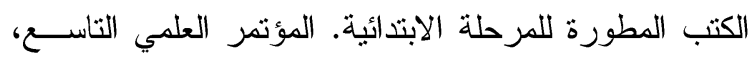
كتب تعليم القر اعة فــي الــوطن العربــي بــين الإنقرائيــة

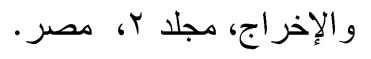

الخطوه الثانية: اشتملت الدالة على متغيــرين مســتقلين و هما: إدراك المبحوثين للمواصفات الفنية و التعليمية لمجلة

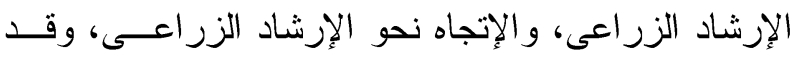

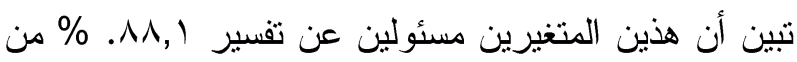
التباين الممكن حدوثه فى المتغير التابع حيث بلغت قيمــة

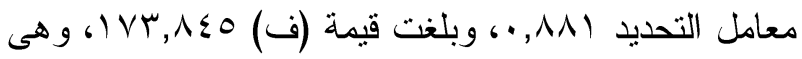
قيمة معنوية عند المستوى الاحتمالى ا •, •. الخطوه الثالثة: اشتملت الدالة علـــى ثنالثــة متغيــر ات مستقلة، وهم: إدراك المبحوثين للمو اصفات الفنية و التعليمية

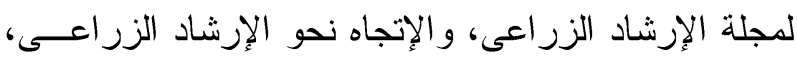

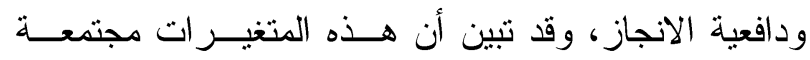
مسئوله عن تفسير 9, 99\% من التباين الممكن حدوثه فـى

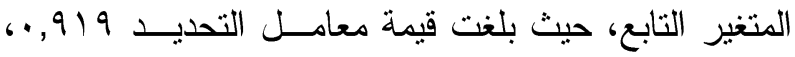

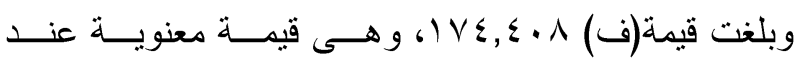
المستوى الاحتمالى 1 •, ••.

الخطوه الر ابعة: الثتملت الدالة على أربعــة متغيــرات مستقلة، وهم: إدراك المبحوثين للمو اصفات الفنية و التعليمية

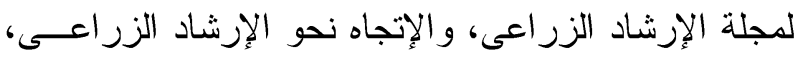

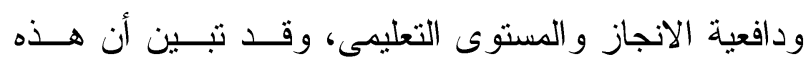
المتغير ات مجتمعة مسئولة عن تفسير 0,بو\% من التبــاين

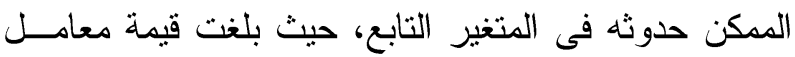

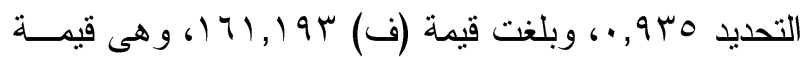
معنوية عند المستوى الاحتمالى I •,.•. الخطوه الخامسة: انشتملت الدالة على خمسة متغيــرات مستقلة، وهم: إدر الك المبحوثين للمو اصفات الفنية و التعليمية

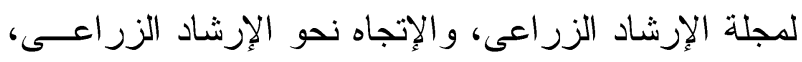

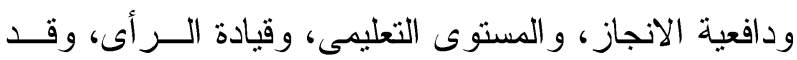

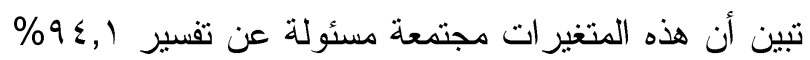

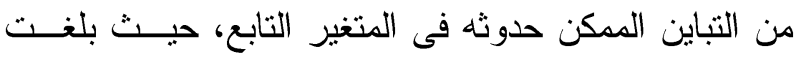




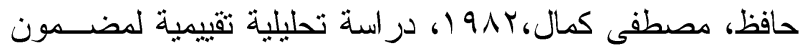

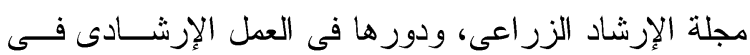
بعض قرى محافظتى الإسكندرية و البحيرة، رسالة دكتور اه، والإنئ كلية الزر اعة جامعة الأسكندرية، الأسكندرية.

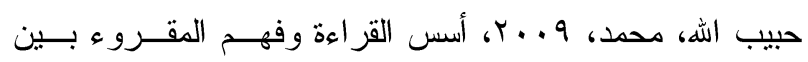
النظرية و النطبيق، طس، دار عمار، عمان، الأردن.

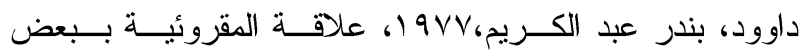

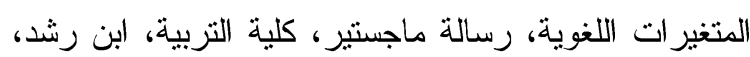
جامعة بغداد.

سليمان، اقبال عبد القـادر محمــد، . . Y، مســتوى مقروئيــة نصوص اللغة العربية المقرر للصف السادس الأساسي فـي مئي

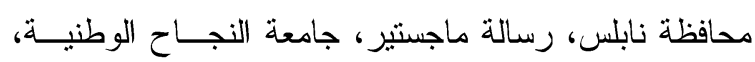
فلسطين. صالح، صبرى مصطفى، ؟ . . ؟، الإرشاد الزر اعى أساســياته وتطبيقاته، مركز اسكندرية للكتاب، الاسكندرية.

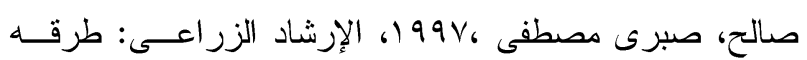
ومعيناته التعليمية، منشور مات جامعة عمر المختار، ليبيا. عثمان، احمد عبد الرحمن إبر اهيم، ل999 1، دراسة صدق وثبات

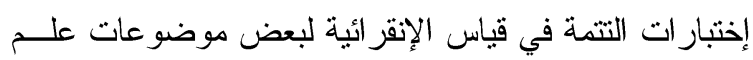

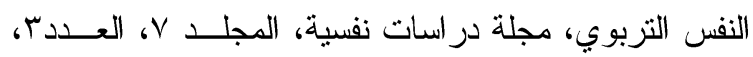
رابطة الأخصائيين النفسيين المصرية، القاهرة. طعيمة، رشدي احمد، مناع، محمد السيد، .... ب، تعليم العربيــة و الدين بين العلم والفن، دار الفكر العربي، القاهرة. كلير، جورج، 911 1، مقياس صلاحية القر اعة، ترجمة ابــر اهيم محمد الثافعي، عمادة شؤون المكتبات، جامعة الملك سعود،

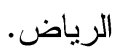

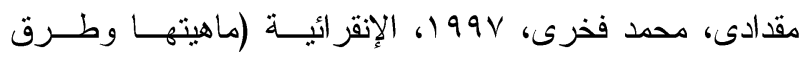

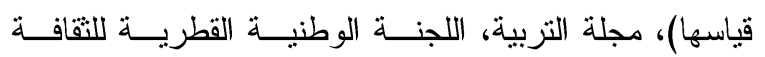

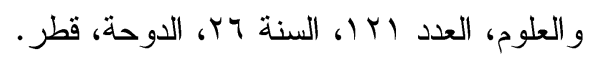

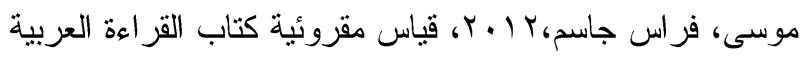

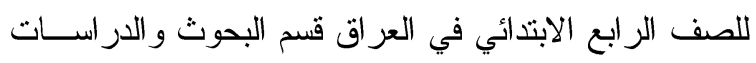

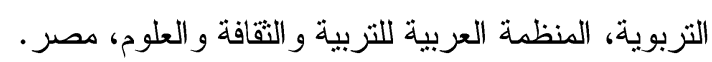

أبو عمشة، خالد حسين، 10 ـ Y، الإنقرائية ماهيتهــا و أهميتهـــا وكيفية قياسها.

Available online: www.alukah.net

أحمد، محمد رياض، ومحمد جــابر، ، . . . . تحسـين مهــارة

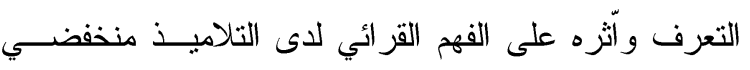

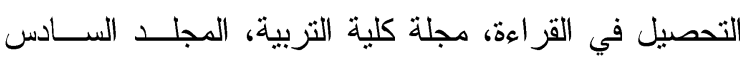

$$
\text { عشر ، العدد(ب)، الأردن. }
$$

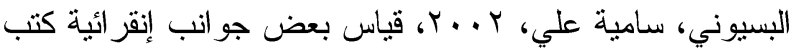

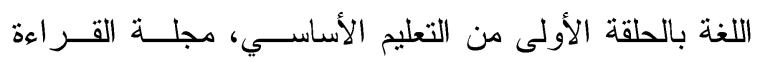
و المعرفة، العددو (، كلية التربية عين شمس.

البردى، عاطف مقبل، ب ا ـ r، مستوى مقروئية كتــاب العلــوم للصف الثانى المتوسط، و علاقته ببعض المتغيرات، رســالة ماجستير، جامعة أم القرى، السعودية. الكلى، حمدى إسماعيل، ^ ـ. . ץ، قياس إنقر ائية كتب اللغة العربية

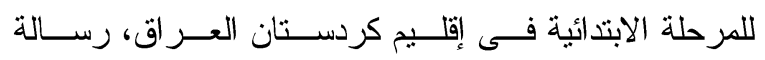
ماجستير، كلية التربية، الجامعة المستتصرية، العراق.

الامهى، رحسيم علــى صــالح، ابتشــام صـــاحب الزوينـى،

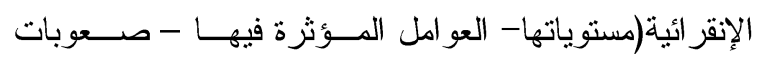

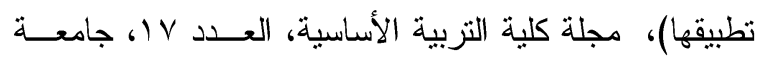
بابل، العر اق.

اللبودي، منى إير اهيم، (9 . . r)، إنقر ائية الكتب الدر اسية المقررة

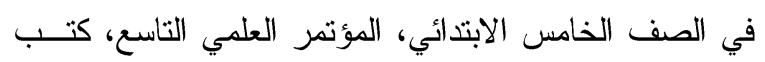

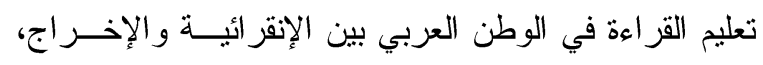

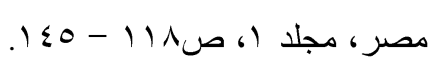

الهاتشمي، عبد الرحمن؛ وعطية، محسن،9 . . r، تحليل محتـوى مناهج اللغة العربية، عمان، دار صفاء للنشر و التوزيع.

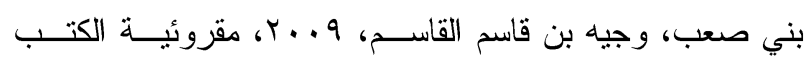
المدرسية، حقيبة تدرييية، الرياض، السعودية.

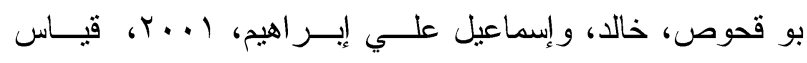

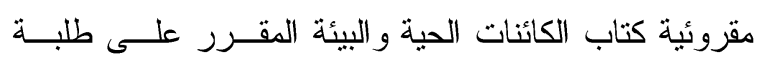

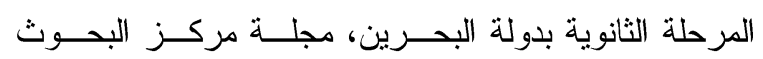

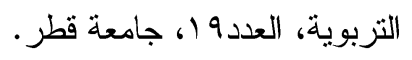




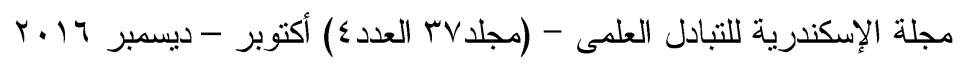

Cotter, Jeanne, 2003. Readability and reading ability: Measurement and Assessment. Southern Illinois University. Edwardsville.

Lu, z. 2002 Readability in Reading Materials Selection and Course book Design for College English in China, PhD Thesis, University of Nottingham.

$$
\begin{aligned}
& \text { يونس، علي إبر اهيم، 9V0 (، الإنقر ائية، مجلة التوثيق التربوي، }
\end{aligned}
$$

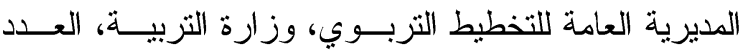

$$
\begin{aligned}
& \text { الثالث عشر، السنة الثالثة، بغداد. }
\end{aligned}
$$

www.aluka.net.

\title{
ABSTRACT \\ Readability of Agricultural Extension Magazine and Variables Affecting it among Members of Boards of Directors of Agricultural Cooperative Associations, ity Elbaroud District
}

\author{
Moustafa Sabry Saleh
}

This study is mainly aiming to study the readability of agricultural extension magazine and variables affecting it among the members of boards of directors of agricultural cooperative associations, Ity Elbaroud District . This will be achieved through the following objectives:

1. Studying some characteristics of the members of the boards of directors of agricultural cooperative associations, Ity Elbaroud District.

2. Identifying the level of readability of agricultural extension magazine among the members of the boards of agricultural cooperative associations, Ity Elbaroud District.

3. Determining the effective variables in readability of agricultural extension magazine among members of the boards of directors of agricultural cooperative associations, Ity Elbaroud District.
Cloze test and data were collected for a random sample of 50 members of the boards of directors of agricultural cooperative associations, Ity Elbaroud District, from 7 random villages, Researcher used a number of statistical methods including percentages, means, frequencies, standard deviation, $\mathrm{t}$ test, $\mathrm{f}$, lsd, simple correlation and multiple regression analysis.

The most important results are summarized as follows:

1. The results showed that $(78 \%)$ of the researched in the readability independent level, (22\%) of the researched in readability educational level, and no researched in frustration level.

2. The results showed that, it was significant variance between the readability of studied agricultural extension magazine topics

3. The results showed that $(94.1 \%)$ from the variance in the dependent variable can be explained by 5 variables. 